\title{
Interleukin-17 and T Helper 17 Cells in Mucosal Immunity of the Lung
}

\author{
M.S. Paats, P.Th.W. van Hal, C.C. Baan, H.C. Hoogsteden, \\ M.M. van der Eerden and R.W. Hendriks \\ Erasmus Medical Center, Rotterdam \\ The Netherlands
}

\section{Introduction}

In all mammals, including humans, the immune system is responsible for the protection against potentially hazardous pathogens, such as bacteria, viruses, parasites and fungi. In this remarkably effective defense system leukocytes, which mediate both innate and adaptive immune responses, play a central role.

The innate immune system comprises granulocytes (neutrophils, eosinophils and basophils), natural killer (NK) cells, mast cells and macrophages. These cells are the first line of defense and provide the immediate response against pathogens. Neutrophils and macrophages can eliminate a pathogen directly by phagocytosis. Moreover, their pattern-recognition receptors, recognizing structurally conserved molecules derived from microbes such as bacterial lipopolysaccharides, unmethylated $\mathrm{CpG}$, or viral double-stranded RNA, allow them to respond to a wide variety of microbial invaders, e.g. by producing cytokines that activate $\mathrm{T}$ lymphocytes of the adaptive immune system.

Acquired or adaptive immunity is characterized by a slower but highly specific immune response. Three major cell types are involved in adaptive immunity: antigen presenting cells (APCs), T lymphocytes and B lymphocytes. Dendritic cells (DCs) are the most potent APCs. They act as messengers between the innate and the adaptive immune system by taking up, processing and presenting antigens to $\mathrm{T}$ lymphocytes. In response to presented antigens, $\mathrm{T}$ lymphocytes may react in different ways: $\mathrm{CD} 4^{+} \mathrm{T}$ helper cells produce various cytokines that direct the immune response, whereas $\mathrm{CD}^{+}$cytotoxic $\mathrm{T}$ cells produce toxic granules that induce death of infected cells. B cells are able to respond to pathogens by terminal differentiation into plasma cells after which they produce large quantities of antibodies. Modulation of $\mathrm{B}$ cell function and antibody production by $\mathrm{CD} 4^{+} \mathrm{T}$ cells is an important step in coordinating immune responses. Upon activation, B cells can migrate to germinal centers, which are specialized structures in secondary lymphoid organs, where they interact with T cells and DCs. Costimulatory signals from T cells then facilitate selection of B cells with high affinity for immunoglobulins and control class switching of the immunoglobulin (Ig) to IgG, $\operatorname{Ig} \mathrm{A}$ and $\operatorname{IgE}$.

Following pathogen elimination, lymphocytes leave a lasting legacy of the antigens they have come across represented by memory cells. As a result, lymphocytes are able to mount a faster and stronger immune response in future encounters with the same antigen. Defective $\mathrm{T}$ cell function can increase susceptibility to infections, allergies and autoimmune diseases. $\mathrm{T}$ 
lymphocytes can however also be manipulated to either eradicate tumor or control graft rejection after organ transplantation. Therefore, in addition to basic biological interest, knowledge on $\mathrm{T}$ cell biology is important to the understanding of the etiology of a wide variety of diseases and may improve current therapies.

During activation in a particular cytokine milieu, naïve $\mathrm{CD} 4^{+} \mathrm{T}$ cells can differentiate into one of the several subsets of T helper (Th) cells. Already in 1986, Mosmann and Coffman introduced the concept of distinct types of T helper cells, which was based on the distinct cytokines profiles that $\mathrm{T}$ cells produce when they are stimulated to differentiate (Mosmann and Coffman 1989). They described two types of Th lymphocytes, type 1 helper T cells (Th1 cells) and type 2 helper T cells (Th2 cells). Th1 cells produce large quantities of interferon $(\mathrm{IFN}) Y$, induce delayed hypersensitivity reactions, activate macrophages, and are essential for the defense against intracellular pathogens. Th2 cells produce mainly interleukin (IL)- 4 and are important in inducing IgE production, recruiting eosinophils to sites of inflammation, and helping to clear parasitic infections. Cytokines produced by cells of the innate immune system govern the differentiation of these $\mathrm{T}$ helper cells. IFNY and IL-12 drive naive T cells into the Th1 pathway, whereas IL-4 initiates the differentiation of naive T cells into Th2 cells. At a molecular level, the differentiation of Th1 and Th2 cells requires specific transcription factors: T-bet for Th1 cells (Szabo et al. 2000) and GATA3 for Th2 cells (Zheng and Flavell 1997) (Figure 1). An additional T helper subset was recently identified which restrains excessive effector $\mathrm{T}$ cell responses and therefore accounts for the maintenance of immune homeostasis and prevention of immunopathology. These cells are called regulatory $\mathrm{T}$ (Treg) cells and are naturally present in the immune system as a functionally distinct $\mathrm{CD} 4^{+} \mathrm{T}$ cell expressing the forkhead transcription factor FoxP3 and producing the cytokines IL-10 and transforming growth factor (TGF)- $\beta$. The differentiation of naïve T cells towards this lineage is driven by IL-2 and TGF- $\beta$ (Weaver and Hatton 2009) (Figure 1). $\mathrm{T}$ follicular helper (Tfh) cells are yet another $\mathrm{CD}^{+} \mathrm{T}$ cell population (Nurieva et al. 2008; Vogelzang et al. 2008). They are important for the formation of germinal centers. Once these germinal centers are formed, Tfh cells are needed to maintain and regulate $\mathrm{B}$ cell differentiation into plasma cells and memory B cells. The signals that specifically instruct the differentiation of human Tfh cells remain unclear, but IL-12 and IL-21 seem to be required. Tfh cells express Bcl6 as their master transcription factor and may produce IL-21 and IL-4 (Yusuf et al. 2010; Ma et al. 2009; Crotty 2011) (Figure 1).

Interestingly, in recent years $\mathrm{T}$ cells were shown to produce proinflammatory cytokines that could not be classified according to this Th1-Th2 scheme. IL-17 is the most prominent amongst these cytokines, and T cells that preferentially produce IL-17 but not IFNY or IL-4 were named Th17 cells. The discovery of this new subset of helper T cells that selectively produces IL-17 has provided better and exciting insights into immunoregulation, host defense and the pathogenesis of autoimmune diseases. In particular, it now appears that Th17 cells do not only play a key role in chronic inflammatory lung disorders, but also mediate protective immunity against various pathogens at respiratory mucosal sites.

\section{Interleukin $\mathbf{1 7}$ and $\mathrm{T}$ helper $\mathbf{1 7}$ cells}

IL-17 (also denoted IL-17A) was cloned in 1993 and initially called CTLA-8 (Rouvier et al. 1993). In 1995, it was renamed as IL-17, its receptor was cloned and it was identified as a cytokine expressed by T cells, exerting effects on epithelial, endothelial, and fibroblast cells (Yao et al. 1995). IL-17 has diverse biological functions, but the best characterized functions 


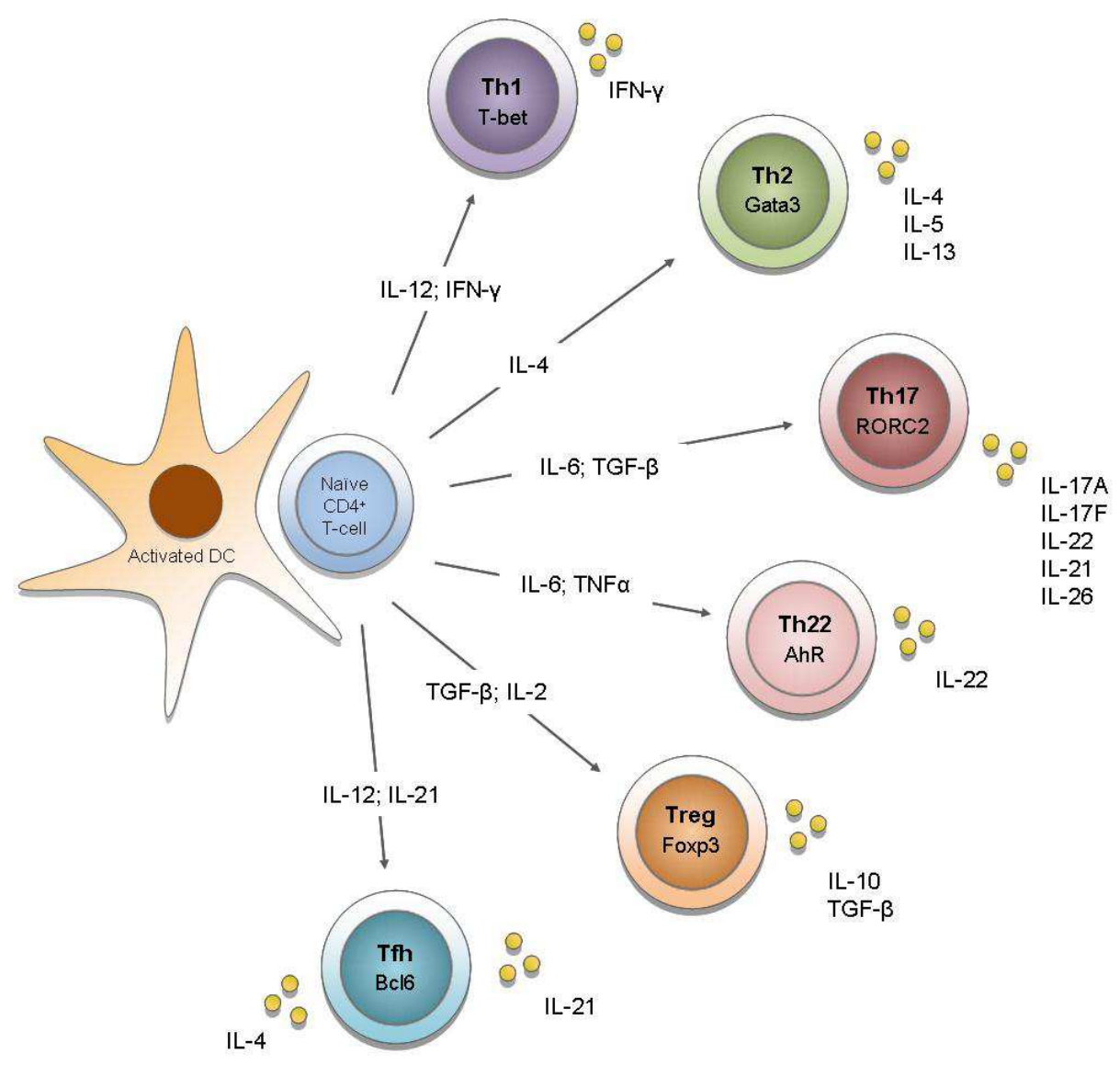

Fig. 1. Overview of human $\mathrm{CD}^{+}$effector $\mathrm{T}$ cell differentiation.

Upon activation in a particular cytokine milieu, naïve $\mathrm{CD} 4^{+} \mathrm{T}$ cells may differentiate into one of several lineages of T helper (Th) cells, including Th1, Th2, Th17, and Treg cells. These separate lineages are characterized by their distinct cytokine production pattern. The differentiation pathways are mainly based on the induction of transcription factors that serve as master regulators of specific lineages. However, cytokine production by Th cells seems to be more flexible than previously believed and recently new cells, such as Th22 and Tfh cells have been described. Whether these new subsets represent distinct lineages remains to be elucidated.

relate to its proinflammatory effects. Specifically, IL-17 recruits neutrophils via effects on granulopoiesis (Schwarzenberger et al. 1998; Fossiez et al. 1996) and CXC chemokine induction, including CXCL8/IL-8 (Laan et al. 1999). Furthermore, it acts on macrophages to promote their recruitment and survival and stimulates the production of proinflammatory cytokines and anti-microbial peptides, particularly $\beta$-defensins, from a variety of immune and non-immune cells (Kolls and Linden 2004; Weaver et al. 2007; Ouyang, Kolls, and 
Zheng 2008; Crome, Wang, and Levings 2010). By now we know that the IL-17 family includes 6 family members: IL-17A, IL-17B, IL-17C, IL-17D, IL-17E and IL-17F. IL-17A and IL-17F are the most closely related isoforms, sharing 55\% homology with each other. Because of their structural and functional similarities and the fact that they are both produced by Th17 cells, IL-17A and IL-17F have been most thoroughly studied and characterized. Although it was known for more than 15 years that IL-17 is a product of activated $\mathrm{CD}^{+} \mathrm{T}$ cells, it was not until 2005 that the Th17 cell was described as a distinct $\mathrm{CD}^{+}{ }^{+} \mathrm{T}$-cell subset, critically responsible for the production of IL-17 in the context of autoimmunity (Harrington et al. 2005).

\subsection{Phenotype and differentiation of Th17 cells}

IL-17A is the hallmark cytokine for Th17 cells. Nevertheless, these cells also produce other cytokines, such as IL-21, IL-22, tumor necrosis factor (TNF)-a, other members of the IL-17 family and, specifically in humans, IL-26 (Dong 2008). As with Th1 and Th2 cells, no single surface marker is specific for Th17 cells. However, human Th17 cells are thought to preferentially express CD161 on the cell surface (Cosmi et al. 2008). Additionally, the selective expression of chemokine receptors in subsets of human memory $\mathrm{T}$ cells has been useful in defining lineages with different effector functions and migratory capacity (Sallusto, Mackay, and Lanzavecchia 2000). It has been shown that human Th17 cells express the chemokine receptor CCR6 and its ligand CCL20 (Dong 2008; Wilson et al. 2007). Coexpression of CCR4 and CCR6 further defines human T cells that produce IL-17 but not IFNY (Acosta-Rodriguez, Rivino et al. 2007). In contrast, expression of CCR6 and CXCR3 identifies a more heterogeneous effector $\mathrm{T}$ cell population that produces both IFNY and IL17 (Acosta-Rodriguez, Rivino et al. 2007). These patterns of chemokine receptors appear to be biologically significant, as memory Th17 cells specific for Candida albicans are mainly $\mathrm{CCR}^{+}{ }^{+} \mathrm{CCR} 4^{+}$positive, whereas those that recognize Mycobacterium tuberculosis antigens are present in the CCR6 ${ }^{+} \mathrm{CXCR} 3^{+}$subgroup producing both IFNY and IL-17 (Acosta-Rodriguez, Rivino et al. 2007; Annunziato et al. 2007).

The combination of cytokines that stimulate differentiation of Th17 cells has been subject of much debate. Initial studies on human $\mathrm{T}$ cell differentiation indicated that $\mathrm{T}$ cell activation in the presence of IL-1 $\beta$, IL- 6 and/or IL-23 was sufficient to induce Th17 cells, and that TGF$\beta$ inhibited this process (Acosta-Rodriguez, Napolitani et al. 2007; Chen et al. 2007; Crome, Wang, and Levings 2010; Wilson et al. 2007). In subsequent studies, however, TGF- $\beta$ was reported to be important for the development of human IL-17 producing cells (Manel, Unutmaz, and Littman 2008; Volpe et al. 2008; Yang, Anderson et al. 2008). This discrepancy could be explained by more recent reports showing that the requirement for TGF- $\beta$ in the differentiation process is indirect and relates to suppression of Th1 differentiation (Crome, Wang, and Levings 2010; Santarlasci et al. 2009). In the current view, the combination of IL$1 \beta$ and IL-6 is essential for proper human Th17 cell differentiation whereas IL-23 is important for both expansion and survival of lineage-committed Th17 cells (Wilson et al. 2007). In addition to cytokine-driven Th17 lineage commitment, it has also been shown that prostaglandin E2 (PGE2), which is a mediator of tissue inflammation, directly promotes differentiation, expansion and proinflammatory function of human and mouse Th17 cells (Yao et al. 2009). In humans, PGE2 induces up-regulation of the IL-23 and IL-1 receptors (IL$23 \mathrm{R}$ and IL-1R, respectively) and by synergism with IL-1 $\beta$, IL-6 and IL-23 (Boniface et al. 2009). 
The observation that Th17 cells are a distinct lineage of cells with a unique cytokine and chemokine/chemokine receptor profile, led to the discovery of RORyt in mice (Ivanov et al. 2006). RORyt encodes the retinoid orphan nuclear receptor, and this transcription factor is required for the differentiation of Th17 cells. In the human system it has also been shown that forced over-expression of RORC2 (the human equivalent of ROR $\mathrm{t}$ ) in human naïve $\mathrm{T}$ cells induces a Th17-like phenotype, by inducing IL-17A, IL-17F, IL-26 and CCR6 expression and down-regulating IFN $\gamma$ secretion (Manel, Unutmaz, and Littman 2008; Crome et al. 2009) (Figure 1). Activation of RORyt also causes expression of the IL23R, indicating that IL-23 acts on T cells that are already committed to the Th17 lineage. Exposure of developing Th17 cells to IL-23 not only enhances the expression of IL-17 but also induces IL-22 and suppresses IL-10 and IFNY (McGeachy et al. 2007). Yet, RORC2 alone can induce IL-17 production in only $20 \%$ of the $\mathrm{T}$ cell population (Chen and O'Shea 2008) indicating that it acts in cooperation with other transcription factors for full commitment of precursors to the Th17 lineage. In addition to RORC2, the most specific and master transcription factor, at least four other transcription factors are linked to the human Th17 cell fate. These include signal transducer and activator of transcription-3 (STAT3), interferon regulatory factor-4 (IRF4), runt box transcription factor-1 (Runx1), and the aryl hydrocarbon receptor (AhR) (Chen and O'Shea 2008). Together they form a sophisticated network with positive and negative feedback loops. In addition, Th17 cells are inhibited by IL-2 (produced by Treg cells), IFNY (produced by Th1 cells), and IL-4 (produced by Th2 cells) but also by other negative regulators such as retinoic acid (Elias et al. 2008).

Although this scheme of T helper cell differentiation might seem complex (Figure 1), it is in fact an oversimplification. Recent studies on $\mathrm{T}$ helper cell differentiation have revealed more plasticity in cytokine production than predicted by conventional models of $\mathrm{T}$ helper cell lineage commitment. Activated memory $\mathrm{T}$ cells preserve plasticity to alter their cytokine program according to the stimuli they receive. A cytokine restricted to one $\mathrm{T}$ helper subset can therefore be secreted by another subset under changing stimulation conditions. This feature is also observed in human Th17 cells (Chen and O'Shea 2008). Acquisition of IFNYproducing potential by Th17 cells, particularly the simultaneous production of IFN $\gamma$ and IL17, is common (Chen et al. 2007; Wilson et al. 2007) (see Figure 2). Additionally, Th17 cells can even stop producing IL-17 and become selective IFN $\gamma$ producers resulting in a complete subset switch (O'Shea and Paul 2010). Although Th1 cells do not become IL-17 producers, under particular circumstances they can make IL-13 (Hayashi et al. 2007). Th17 cells produce IL-22, but cells that make IL-22 and not IL-17 ("Th22 cells") have recently been identified as well (Duhen et al. 2009; Trifari et al. 2009). Simultaneous production of IL-22 and IFNY has also been described (O'Shea and Paul 2010). This plasticity even concerns master regulators: FoxP3 expression within Treg cells is heterogeneous and transient and former.

Treg cells have the capacity to produce proinflammatory cytokines such as IL-17 (Bluestone et al. 2009).

Moreover, also multiple master regulators can be expressed, such as Gata3 and FoxP3 in Tregs (Mantel et al. 2007), or a combination of RORC2 and FoxP3 (mixed Th17-Treg) (O'Shea and Paul 2010). Therefore, expression of master regulators should not be simplified as mutually exclusive but rather as a gradient of transcription factors (O'Shea and Paul 2010). It remains to be shown whether there are preferential directions for plasticity or whether effector $\mathrm{T}$ cells can change in any direction from every starting point (Bluestone et al. 2009). Plasticity could be an answer to the evolution of pathogens, allowing a proper response to new threats. 


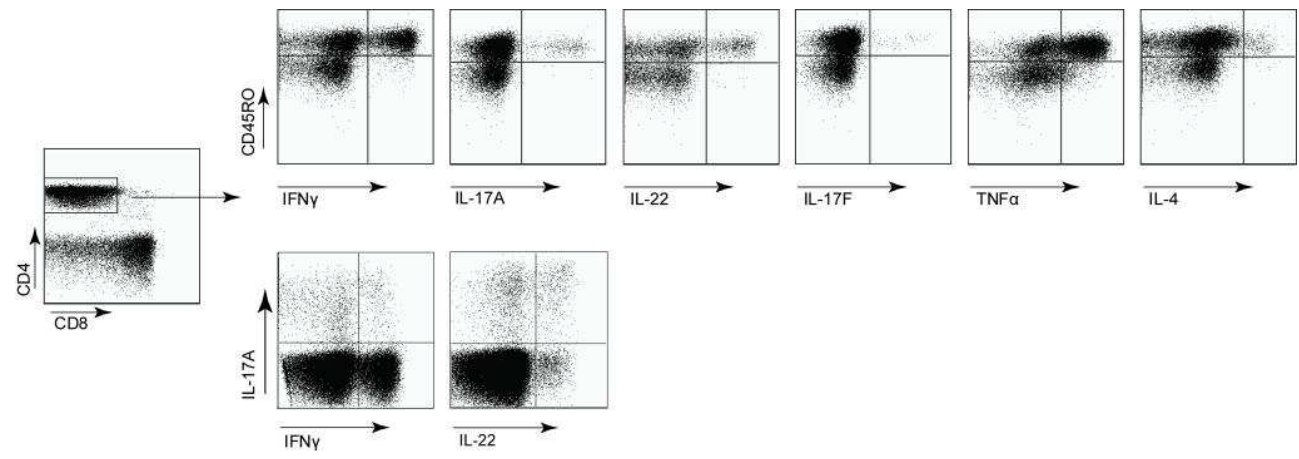

Fig. 2. Flow cytometric analysis of cytokine production by $\mathrm{CD} 4^{+} \mathrm{T}$ helper cells.

With the use of a technique called flow cytometry, it is possible to depict the cytokine producing potential of individual cells. In this experiment peripheral blood mononuclear cell (PBMC) suspensions were stained with monoclonal antibodies specific for CD3, CD4, $\mathrm{CD} 8$, and the indicated cytokines. Live $\mathrm{CD} 4{ }^{+} \mathrm{CD} 3^{+} \mathrm{T}$ cells were gated and analyzed for the presence of the indicated cytokines in combination with the CD45R0 marker for memory $\mathrm{T}$ cells. Results are shown as dot plots and illustrate that $\mathrm{CD}^{+} \mathrm{T}$ helper cells are capable of producing all of the tested cytokines (top row, right upper quadrants). Moreover, $\mathrm{CD}_{4}^{+} \mathrm{T}$ helper cells have the potential to be simultaneously positive for IL-17 and IFN $\gamma$, and IL-17A and IL-22 respectively (bottom row, right upper quadrants).

\subsection{IL-17 producing cells other than Th17 cells}

Th17 cells are not the exclusive producers of IL-17 nor is this production their only function. Other cell populations capable of producing IL-17 include both adaptive and innate immune cells.

Within the adaptive arm of the immune system, a subset of $\mathrm{CD}^{+}$cytotoxic $\mathrm{T}$ cells is also capable of producing IL-17. Studies have shown that these cells develop under conditions that are similar to those required by Th17 cells, but different from those required by IFNY producing $\mathrm{CD}^{+} \mathrm{T}$ cells (Kondo et al. 2009). However, adaptive immune responses cannot explain the early IL-17-mediated immune responses that have crucial roles during stress responses and host defense. Early responses are induced within hours following tissue injury or exposure to pathogens (Ferretti et al. 2003; Happel et al. 2003; Zheng et al. 2008), which is not enough time to allow for Th17 differentiation, indicating that innate immune cells play a crucial role in these early responses. The key feature of this innate IL-17 response is the early neutrophil recruitment. This results in a more efficient resolution of infection, in the maintenance of mucosal barrier integrity, but also in the potential induction of autoimmunity (2). Recent studies have shown that $\gamma \delta \mathrm{T}$ cells are important innate-like IL-17producing cells during infectious diseases and autoimmune inflammation (Aujla, Dubin, and Kolls 2007; Sutton et al. 2009; Ito et al. 2009). Additionally, innate(-like) IL-17-producing cells described in literature include $\mathrm{CD}^{+}$invariant natural killer T (iNKT) cells, lymphoid tissue inducer (LTi)-like cells, natural killer (NK) cells and myeloid cells (Cella et al. 2009; Cua and Tato 2010; Michel et al. 2007).

The $\gamma \delta \mathrm{T}$ cell subset is an innate-like immune cell population that has an important role at the mucosal barrier. These cells do not express the classical $\alpha \beta$ T cell receptor (TCR) but a $\gamma \delta$ TCR instead. They bind to epitopes in much the same way as antibodies do and provide a 
rapidly available source of IL-17 (Sutton et al. 2009). Like $\gamma \delta \mathrm{T}$ cells, iNKT cells play a pivotal role in immunity as they provide a rapid response, with the capacity to critically amplify and regulate adaptive immune responses (Godfrey et al. 2004). Initially, they have been divided into subsets that produce either IL-4 or IFN $\gamma$, but recently a new IL-17producing subset that develops in the thymus has been described. This subset seems already committed to making IL-17 (Michel et al. 2008). The LTi cell represents a primitive precursor of NK, NKT, and CD4 ${ }^{+} \mathrm{T}$ cells. Specifically immature $\left(\mathrm{CD} 127^{+}\right) \mathrm{NK}$ cells are closely related to LTi cells (Eberl et al. 2004). LTi cells promote the formation of lymphoid organs and sustain primed CD4+ $\mathrm{T}$ cell memory responses (Eberl et al. 2004). Thus, like IL-17 producing $\gamma \delta \mathrm{T}$ cells and NKT cells, LTi cells provide a rapidly available source of IL-17. Interestingly, it was recently recognized that innate lymphoid cells (ILCs) can be considered a family of non-T/non-B lymphocytes that includes not only NK and LTi cells, but also cells that produce IL-5, IL-13, IL-17 or IL-22. These ILC subsets are developmentally related and require cytokine signals through the common $\gamma$-chain of the IL-2 receptor. The distinct ILC subsets, which seem to have important roles in protective immunity analogous to helper $\mathrm{T}$ cell subsets, were recently reviewed by Spits and DiSanto (Spits and Di Santo 2011). Next to LTi and NK cells, other innate IL-17 producers have been postulated, including macrophages and neutrophils (reviewed by (Cua and Tato 2010; Song et al. 2008), however data is limited and further studies are needed to understand more of their role in mucosal tissue.

\subsection{Interactions between Th17 and other cells of the immune system}

Cells of the immune system modulate each other's function. Many cells may interact with Th17 cells including APCs, other T helper subsets, B cells and neutrophils (Figure 3). APCs play a central role in directing immune responses by secreting cytokines that polarize CD4 ${ }^{+}$ $\mathrm{T}$ cells into distinct lineages. Several studies support the hypothesis that changes in APC function probably precede inappropriate development and expansion of Th17 cells. For example, monocytes from inflamed joints of rheumatoid arthritis patients promote the development to Th17 cells but not Th1 or Th2 cells via a cell-contact-dependent mechanism (Evans et al. 2009). Furthermore, it was found that monocyte-derived DCs from patients with multiple sclerosis secrete elevated levels of IL-23 when compared to healthy controls (Vaknin-Dembinsky, Balashov, and Weiner 2006). Additionally, in psoriasis DCs secrete IL$1 \beta$, IL-23 and CCL20, promoting both the development of Th17 cells and their migration to the skin (Kryczek et al. 2008). However, the initial stimuli that polarize APCs to produce cytokines that promote Th17 cells are still unclear.

It has long been known that Th1 and Th2 cells antagonize each other's differentiation and function. Not surprisingly, IFNY produced by Th1 cells and IL-4 produced by Th2 cells inhibit Th17 development (Bettelli, Oukka, and Kuchroo 2007). For Treg cells and Th17 cells there appears to be an even closer developmental relationship because the differentiation of both of these cell types require transforming growth factor (TGF) $\beta$ (Veldhoen et al. 2006). Additionally, Th17 differentiation is inhibited by Treg cells, via the production of IL-2. Th17 cells can also modulate B cell function as has been shown by their ability to promote antibody production (IgM, IgG and IgA but not IgE) (Acosta-Rodriguez, Napolitani et al. 2007).

There is growing evidence that $\mathrm{T}$ cells are involved in orchestrating sustained mobilization of neutrophils. In the lungs for instance, in a subpopulation of COPD patients there is an accumulation of $\mathrm{CD}^{+}$and $\mathrm{CD} 8^{+} \mathrm{T}$ cells, which is associated with the presence of neutrophils 


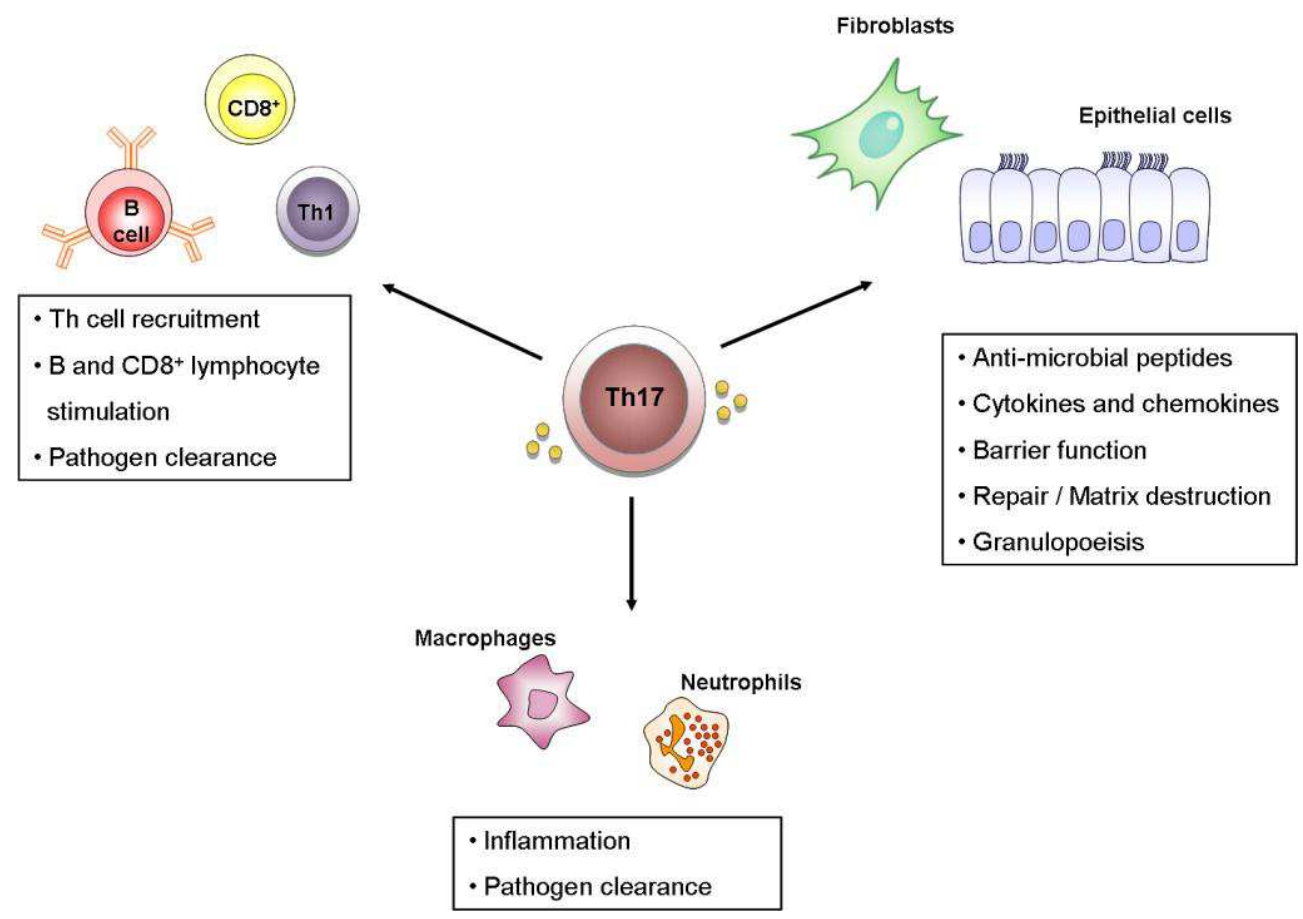

Fig. 3. Th17 cells act on other immune cells and on cells of non-hematopoietic origin. Cytokines produced by Th17 cells have the ability to act on other cells. This allows for a crosstalk between immune and non-immune cells to provide protection and promote inflammation.

(Turato et al. 2002). IL-17 seems to be an important mediator of linking activated T cells to accumulation of neutrophils, although solid data on T helper cells and neutrophils are lacking. In vitro work confirmed that IL-17 orchestrated neutrophilic influx by the production of CXCL8 (IL-8), CXCL1 (GRO-a), and granulocyte-macrophage colony stimulating factor (GMCSF) in airway epithelial cells, smooth muscle cells, endothelial cells, and fibroblasts (Murphy et al. 2008). So, the importance of Th17 cells in neutrophilic inflammation lies in the ability of IL-17 to induce granulopoiesis, neutrophil chemotaxis, and the anti-apoptotic properties of GCSF (Kolls and Linden 2004; Ouyang, Kolls, and Zheng 2008). Accordingly, administration of IL-17A to the lung induces robust neutrophil recruitment (Laan et al. 1999), although - by contrast - chronic IL-17A/F overexpression resulted in enhanced lymphocyte and macrophage but not neutrophil numbers (Park et al. 2005; Yang, Chang et al. 2008).

\section{IL-17 in lung diseases}

Although Th17 cells have only recently been recognized as a distinct lineage of CD4+ $\mathrm{T}$ cells, associations between IL-17 and human disease have been known for many years. Particularly disorders previously classified as typical Th1 disease, such as rheumatoid arthritis (Kotake et al. 1999), inflammatory bowel disease (Fujino et al. 2003), and psoriasis (Arican et al. 2005), are now considered to be primarily Th17-driven. For that reason 
(chronic) lung conditions previously believed to be Th1 cell disorders deserve special attention as Th17 cells might contribute to their pathogenesis. Moreover, immunity mediated by Th17 cells seems particularly important at epithelial and mucosal surfaces, as indicated by the distinct pattern of expression of Th17 subset-associated chemokine and cytokine receptors (Aujla et al. 2008; Ouyang, Kolls, and Zheng 2008).

Because Th17 cells and IL-17 play a role in regulating neutrophilic and macrophage inflammation in the lung, a potential role in many different lung diseases including asthma and chronic obstructive pulmonary disease (COPD), cystic fibrosis (CF), pulmonary infectious diseases, sarcoidosis and other interstitial lung diseases and rejection after lung transplantation, seems legitimate. Asthmatics were shown to have elevated levels of IL-17A mRNA and protein levels in induced sputum and these levels were positively correlated with disease severity (Bullens et al. 2006; Molet et al. 2001; Al-Ramli et al. 2009). In COPD, recent studies showed increased expression of Th17 cytokines in bronchial mucosa and sputum (Di Stefano et al. 2009; Doe et al. 2010). Airway neutrophilia is a major feature of CF exacerbations and it is shown that sputum IL-17 is upregulated and correlates with Pseudomonas aeruginosa colonization (Dubin and Kolls 2007). In infection models in mice, there is considerable evidence that IL-17 and/or IL-23 are important in host responses against Klebsiella pneumoniae (Tesmer et al. 2008). Furthermore, several studies have now linked IL-17 to fibrosis in the lung in mouse models of pulmonary fibrosis and idiopathic pulmonary fibrosis in humans (Braun et al. 2010; Kurasawa et al. 2000; Wilson et al. 2010). Similarly, Th17 cells and IL-17 may be important regulators of the airway fibrotic response driving the development of bronchiolitis obliterans syndrome (BOS) upon lung transplantation.

For functional analysis of IL-17 producing cells in relation to other immune cells or epithelial cells, it is important to consider their anatomical localization. Obviously, bronchoscopy-guided or surgically guided biopsies allow histopathologically examination in situ, but are not frequently performed because they are invasive techniques. Bronchoalveolar lavage (BAL) is again not commonly performed except in lung transplantation and interstitial lung disease. For this reason sputum and nasopharyngeal washes are often studied. Blood and serum might be ideal to study because they are easily accessible. However, it is not always clear to what extend these compartments reflect what is happening in the lung. The methodology to study IL-17+ $\mathrm{T}$ cells in biopsies or in serum and BAL represents only indirect evidence of Th17 cells. Flow cytometry does provide direct evidence as it can combine several parameters (Figure 2). In this way, identification of distinct IL17+ $\mathrm{T}$ cells and even separate subpopulations is relatively simple.

\subsection{COPD and asthma}

COPD and asthma represent two classes of chronic obstructive lung disorders that may share some similar immunological disease mechanisms. COPD is marked by a progressive and irreversible airway obstruction and emphysematic changes in the lung. In asthma the airway obstruction is reversible and there is a marked airway hyperresponsiveness and airway inflammation. Recent studies on the immunological mechanisms of COPD and asthma pathogenesis point towards a role for IL-17 and Th17 cells in both diseases.

\subsubsection{COPD}

In COPD, chronic inhalation of toxic particles and gases causes destruction of lung parenchyma, activates epithelial cells, increases mucus production and stimulates migration 
of many inflammatory cells (Hogg 2004; Hogg et al. 2004). This results in an abnormal inflammatory response in the small airways and alveoli. It is believed that both the innate and the adaptive immune system are involved in this inflammatory process (Barnes 2008; Hogg et al. 2004). Progression of the disease is associated with the presence of lymphoid follicles, a histological hallmark of an adaptive immune response and termed bronchusassociated lymphoid tissue (BALT) collections. The presence of neutrophils, BALT collections, autoantibodies in the lungs, and also autoreactive $\mathrm{T}$ cells in the periphery, indicate $\mathrm{CD}^{+} \mathrm{T}$ cell involvement in the pathogenesis of COPD (Curtis, Freeman, and Hogg 2007; Feghali-Bostwick et al. 2008; Hogg et al. 2004; Vanaudenaerde et al. 2011). A potential role for adaptive immune responses in COPD has also been suggested in studies that show expansion of lung $\mathrm{T}$ and $\mathrm{B}$ cells with oligoclonality in patients with COPD and in murine emphysema models (Motz et al. 2010; Sullivan et al. 2005). To date, there are only few studies examining the expression of IL-17A and IL-17F in COPD. However, since neutrophilic inflammation (including elevated CXCL8 levels) is a common feature of COPD (Barnes 2000), and infiltrating CD4 ${ }^{+} \mathrm{T}$ cells in COPD were previously considered to be Th1 cells, it is expected that Th17 cells play an important role in this disease.

Although direct evidence for the role of IL-17 and Th17 cells in COPD remains largely absent, the importance of IL-17 in stimulating chemokine production and the role of neutrophils and macrophages in promoting COPD pathogenesis have led to interest in a potential connection (Curtis, Freeman, and Hogg 2007). Another possible link derives from the ability of IL-17 to drive matrix metalloproteinases (MMP)9 production, a protein which is involved in the breakdown of extracellular matrix, as is observed in emphysema (Prause et al. 2004). It is also known that IL-17-mediated signalling induces target cells to produce various inflammatory mediators such as TNF- $\alpha$, IL-6 and IL-1 $\beta$. Interestingly, increased levels of IL-6 and TNFa are found in sputum and BAL fluid and have been associated with disease severity in patients with COPD (Hacievliyagil et al. 2006). TNFa promotes CXCL8 expression from airway epithelial cells. Elevated levels of serum TNFa have also been linked to exacerbations in COPD patients (Calikoglu et al. 2004). In addition TNFa production by mast cells is increased due to IL-17A, leading to neutrophil infiltration in the airways (Feldmann et al. 2001). Furthermore, IL-17 is capable of increasing mucin production from airway epithelial cells (Prause et al. 2004) and excessive mucus production is one of the characteristic of COPD. Recently it was shown that patients with stable COPD exhibited elevated numbers of IL-22- and IL-23-positive cells in the bronchial epithelium and IL-17-positive cells in the submucosa when compared to healthy controls (Di Stefano et al. 2009; Doe et al. 2010; Chang et al. 2011). Additionally, airway smooth muscle cells from COPD patients express IL-17RA and respond to IL-17 by inducing CXCL8 production (Rahman et al. 2005). In contrast to these findings, the levels of IL-17 in sputum from patients with COPD do not differ from control subjects (Barczyk, Pierzchala, and Sozanska 2003). In addition to human studies, mice exposed to cigarette smoke exhibit enhanced IL-17 production (Melgert et al. 2007; Harrison et al. 2008). Experiments on murine lung epithelial cells have also shown that overexpression of IL-17A induces a COPD-like lung inflammation (Park et al. 2005). Taken together, these findings indicate a role for Th17 cells in COPD, but it is still unclear whether and how these cells contribute to disease pathogenesis or progression. Moreover, to what extend Th1 and Th17-mediated immune responses affect airway obstruction, emphysematic changes, inflammation or COPD exacerbations are questions that need to be addressed. 


\subsubsection{Asthma}

Asthma is usually characterized by concurrent airway inflammation, cytokine production, and airway hyperresponsiveness to relevant antigens and a specific trigger. The central role of the Th2 subset in the disease, inducing airway eosinophilia and bronchial hyperresponsiveness, is well accepted. Individually, the Th2 cytokines can explain many of the salient features of asthma, including IgE induction in B cells (IL-4), airway eosinophilia (IL-5) goblet cell hyperplasia (IL-4, IL-13) and bronchial hyperreactivity (IL-13 acting on bronchial smooth muscle cells) (Wills-Karp et al. 1998). However, some individuals with asthma display airway neutrophilia rather than eosinophilia (Anderson 2008). It appears that in those patients with asthma in which inflammation is nonatopic, non-IgE-dependent, and noneosinophilic, airway neutrophilia is correlated with asthma severity. This suggests a major role for neutrophils, at least in this subset of patients with asthma (Louis et al. 2000). Neutrophilic inflammation has also been described in sudden-onset fatal asthma and neutrophil numbers are highly elevated in status asthmaticus (Lamblin et al. 1998). These observations suggest a role for these cells in severe and fatal asthma (Cosmi et al. 2011). With the involvement of neutrophils, several studies tried to find an association between Th17 lymphocytes and asthma.

Asthmatics have elevated levels of IL-17A mRNA and protein in breath condensate, sputum, BAL, and airway biopsies (Bullens et al. 2006; Pene et al. 2008; Molet et al. 2001). Furthermore, increased IL-17A and IL-17F levels are positively correlated to disease severity, suggesting an important role for IL-17A and IL-17F in severe asthma (Al-Ramli et al. 2009). Indeed, elevated IL-17A levels also correlate to increased neutrophilic inflammation, a characteristic of severe and steroid-resistant asthma (Bullens et al. 2006). One could also hypothesize that IL-17 may have opposite pathophysiological roles in different disease stages, as would be supported by findings in an asthma mouse model, indicating that IL-17A is required for induction of disease but negatively regulates established asthma (Schnyder-Candrian et al. 2006). IL-17F may also play an important role in the development of asthma, as a polymorphism in IL-17F which results in a loss-offunction mutation, is inversely related to asthma risk (Hizawa et al. 2006). In these studies however, the cellular source of IL-17 remained unknown, but recent studies attributed the production of IL-17 primarily to CD4 ${ }^{+} \mathrm{T}$ cells (Pene et al. 2008; Tesmer et al. 2008). A novel subset of Th2 memory cells that co-express the key Th2 and Th17 transcription factors, GATA3 and RORCT, respectively, and coproduce Th2 and Th17 cytokines was recently described (Wang et al. 2010). Interestingly, the number of IL-17+ Th2 cells was significantly increased in peripheral blood of atopic asthma patients. Compared with classical Th17 or Th2 cells, these IL-17+ Th2 cells had an increased capacity to induce influx of inflammatory leukocytes, and therefore are thought to represent key pathogenic cells promoting exacerbation of allergic asthma.

\subsection{Pulmonary infections}

There is considerable evidence that IL-17 and other Th17 cytokines are important in pulmonary host responses to infection by a variety of different bacteria, fungi and protozoa, and viruses. Also in infection, the major function of IL-17 appears to be to promote chemokine and pro-inflammatory cytokine production and consequent recruitment and activation of neutrophils and macrophages. Additionally, Th17 cytokines can control the infection by induction of anti-microbial peptides during the early immune responses at mucosal sites. Upon stimulation with various microbial agents, activated DCs secrete 
cytokines which determine the type of adaptive immunity that develops, i.e., whether the immune response is skewed toward Th1 or Th17 cells. Nevertheless, Th17 responses do not always seem to have a protective effect in mucosal infections. Current studies suggest that limited and correctly timed Th17 responses are protective, when appropriately balanced with concurrent Th1 immunity, but that uncontrolled Th17 cell activity could lead to a counterproductive level of organ inflammation (Tesmer et al. 2008).

Human studies on the role of IL-17 and Th17 cells in pulmonary infections are limited. The best human "model" demonstrating the role of IL-17 and Th17 cells in clearing pulmonary infections is Job's syndrome or the hyper-IgE syndrome. This syndrome is caused by loss-offunction mutations in STAT3, resulting in the inability of naïve T cells to differentiate into Th17 cells. These patients manifest chronic, recurrent and severe bacterial and fungal infections (Milner et al. 2008). Although other factors such as disturbed neutrophil chemotaxis are also involved in hyper-IgE syndrome (Hill et al. 1974), the Th17 cell deficiency is prominent. This therefore suggests an essential role for Th17 cells in the host immune system.

\subsubsection{Bacteria}

The host response to bacteria is largely triggered by Toll like receptor (TLR) ligands stimulating the production of inflammatory mediators, such as the pro-inflammatory cytokines IL-1 $\beta$, IL-6 and TNFa, and the recruitment of phagocytic cells to the lung (Akira, Uematsu, and Takeuchi 2006). Several components of the innate immune system have been identified as key mediators of bacterial clearance such as neutrophils and macrophages. The role of Th17 cells in bacterial pneumonia is less clear. However, HIV patients with depleted $\mathrm{CD}^{+} \mathrm{T}$ cells are more susceptible to bacterial infections in the lung (Wolff and O'Donnell 2003), indicating a role for T cells in bacterial pneumonia.

One of the best studied bacterial pathogens in pulmonary host defense is Klebsiella pneumoniae. Klebsiella pneumoniae is a virulent Gram-negative pathogen that can cause pneumonia. In mice infected with this organism, TLR4 activation in the lung leads to production of IL-23 by DCs, which then stimulates $\mathrm{CD}^{+}, \mathrm{CD}^{+}$and even $\gamma \delta \mathrm{T}$ cells to release IL-17 (Happel et al. 2003). Interestingly, both IL17A and IL17F are induced in a dosedependent fashion (Aujla et al. 2008; Happel et al. 2005). Accordingly, the protective effects of IL-17 in host defense against bacterial pathogens were shown in studies that compared the susceptibility of IL-17R-deficient and control mice to K. pneumoniae infection (Ye et al. 2001). After intranasal infection, IL-17R-deficient mice were more susceptible to lung infection with K. pneumoniae (Happel et al. 2005; Ye et al. 2001). The increased bacteraemia and mortality observed in these mice were associated with delayed neutrophil recruitment and reduced expression levels of CXCL1, CXCL2, and G-CSF in the lung 12-24 hrs after infection. Related experiments demonstrated the essential role of IL-23 in triggering IL-17 production during this infection. Also IL-23-deficient mice are highly susceptible to $K$. pneumoniae and do not upregulate IL-17 in response to infection, whereas IL-17 production readily occurs after infection in control mice (Happel et al. 2005). Furthermore, administration of recombinant IL-17 restores the early chemokine response, enhances local production of TNFa and IL-1 $\beta$, and reduces the bacterial burden in IL-23-deficient mice after K. pneumoniae infection (Happel et al. 2005; Ye et al. 2001). Together, these findings demonstrate that IL-17 produced in an IL-23-dependent fashion is essential for early recruitment of neutrophils and other inflammatory cells to provide immunity to $K$. 
pneumoniae infection. In these studies it was also shown that in addition to IL-17 also IL-22 is measurable during infection. In contrast to gene deletion of IL-17, which results in a substantial reduction of CXCL1 and G-CSF in response to bacterial challenge, antibody neutralization of IL-22 causes an even more profound defect in mucosal immunity that leads to rapid dissemination of bacteria from the lung to the spleen (Aujla et al. 2008). The loss of mucosal immunity was not associated with defects in G-CSF or CXCL1 but with loss of barrier function and anti-microbial protein expressed in lung epithelium. Thus while IL-17 production by Th17 cells is critically important in host defense against K. pneumoniae infection in the airway because of its role in neutrophil recruitment and activation, IL-22 acts by augmenting the barrier defense against pathogens by triggering the production of antimicrobial peptides and enhancing healing of the epithelium should it be breached (Aujla et al. 2008). Importantly, not only Th17 responses are necessary for optimal protective immunity to K. pneumonia. Also IL-12-driven Th1 responses, resulting in efficient IFNY production, contribute to the optimal bacterial clearance in a mouse model of K. pneumonia (Happel et al. 2005).

Following these initial studies with K. pneumoniae, the importance of IL-23 and IL-17 in host defense has been further established for a growing list of pathogens. Similar to $K$. pneumoniae, in mice infected with Mycoplasma pneumoniae, infiltration of the lungs by neutrophils is dependent on IL-23-induced upregulation of IL-17 (Wu et al. 2007). Additionally, accumulating evidence suggests that another Gram-negative extracellular respiratory pathogen, Bordetella pertussis which causes the whooping cough, may bias the host response towards the production of Th17 cytokines by preferentially inhibiting IL-12 and inducing IL-23 (Fedele et al. 2008). The above-referenced studies clearly demonstrate a protective role for Th17 effector cytokines in host defense against primary challenges with specific extracellular Gram-negative pathogens. Th17 response may also play a role in controlling primary infection with intracellular pathogens such as Mycobacterium tuberculosis, although a much more limited one when compared with extracellular bacterial pathogens. It was shown that although Th17 cells are not critical to the primary response to M. tuberculosis, Th17 activation is clearly involved in response to vaccination against tuberculosis (Khader et al. 2007). In addition to this Th17-mediated vaccine-induced immunity to $M$. tuberculosis, Th17 cytokine responses have also been implicated in vaccineinduced immunity against B. pertussis (Higgins et al. 2006) and Streptococcus pneumoniae (Malley et al. 2006). This indicates that the host Th17 effector cytokines have evolved as protective immune mechanisms against extracellular bacteria but are dispensable for primary protection against most intracellular pathogens that require a Th1 pathway for protection, such as in tuberculosis infection.

Pseudomonas aeruginosa is another Gram-negative pathogen. Although not as virulent as $K$. pneumoniae, $P$. aeruginosa is a highly adaptable pathogen that causes both acute and chronic pulmonary infections. Chronic colonization and infection in the lung is associated with preexisting airway disease such as CF. CF is a disease characterized by the excessive production of aberrantly hydrated mucus in the airways, resulting from mutations in the ion channel cystic fibrosis transmembrane conductance regulator (CFTR). This increased mucus production, blocks normal ciliary function and thereby enhances recurrent pulmonary infections. During pulmonary exacerbation, CF patients exhibit airway neutrophilia and elevated levels of IL-23 and both IL-17A and IL-17F in bronchoalveolar lavage fluid and sputum (McAllister et al. 2005). Recently it was shown that CD4+ $\mathrm{Th} 17$ cells are prominently 
featured in the airway walls of CF patients but that NKT cells and $\gamma \delta \mathrm{T}$ cells are also sources of IL-17 in patients with CF (Tan et al. 2011). In the latter study, IL-17+ cells were correlated with $\mathrm{CF}$ and non-CF bronchiectasis, but not with the presence of $P$. aeruginosa. It has been shown that clearance of $P$. aeruginosa is dependent on Th17 responses (Dubin and Kolls 2007).

\subsubsection{Fungi, viruses and other opportunistic pathogens}

Several reports from mouse and human studies have shown that Th17 cells are important for clearing opportunistic infections such as Cryptococcus neoformans, Pneumocystis jirovecii and Candida albicans. E.g. patients with Job's syndrome are extremely susceptible to mucocutaneous fungal infections caused by Candida species. It has been suggested that Th17 cytokines, particularly IL-17, contribute to tissue pathology in invasive Aspergillus infection in the lung particularly in the setting of NADPH oxidase deficiency (Romani et al. 2008). In respiratory tract models of fungal infections using $P$. jirovecci, induction of IL-23 and IL-17 following pathogen challenge is protective, since IL-23KO mice or neutralization of the IL-23/IL-17 axis resulted in impaired clearance of the pathogen (Rudner et al. 2007).

Human viruses can induce IL-17 responses, as shown for herpes simplex virus (Maertzdorf, Osterhaus, and Verjans 2002) and respiratory syncytial virus (Hashimoto et al. 2005). Human rhinovirus infections are associated with exacerbations of asthma and COPD and IL-17 was shown to function synergistically with human rhinovirus to induce IL-8 from epithelial cells. This may contribute to the recruitment of neutrophils, immature DCs and memory $\mathrm{T}$ cells to the lung contributing to severe inflammatory profiles seen during viral exacerbations of airway disease (Wiehler and Proud 2007).

Taken together, there is accumulating evidence for the involvement of IL-17 in bacterial, fungal and viral infection in the respiratory system in the mouse, whereas in human the role of IL-17 or Th17 cells is largely unexplored.

\subsection{Sarcoidosis, pulmonary fibrosis and other interstitial lung diseases}

Interstitial lung diseases (ILD) refer to a very heterogeneous group of lung diseases affecting the lung parenchyma. The exact nature of the initiating event and the subsequent cascade of mechanistic proceedings are most likely different in every single ILD. Multiple factors are likely to be involved but it is now clear that the immune system plays a major part in the pathogenesis of ILD. A similarity in every ILD is the interaction of growth factors, cytokines, and other mediators with cells that reside in the lung which seem to form part of the cascade of events that have been identified in the pathogenesis.

Recent data point to a potential role of IL-17 and Th17 cells in a number of ILD. E.g. Wegener granulomatosis (Abdulahad et al. 2008), Langerhans histiocytosis (Coury et al. 2008), and hypersensitivity pneumonitis (Joshi et al. 2009; Simonian et al. 2009) have been reported to be linked to IL-17. Pulmonary IL-17 producing $\gamma \delta ~ T$ cells have also been detected in response to bleomycin-induced tissue damage, a model for induced pulmonary fibrosis (Braun et al. 2010). Conversely, a particular subset of $\gamma \delta \mathrm{T}$ cells secreting IL-17 has been shown to contribute to hyperinflammatory granulomatous disease and fatal lung tissue damage during pulmonary aspergillosis (Romani et al. 2008). Recently, also sarcoidosis was suggested as a Th1/Th17 multisystem disorder (Facco et al. 2011), based on the presence of IL-17 positive $\mathrm{CD}^{+} \mathrm{T}$ cells in sarcoid lung tissue and their ability to respond to the chemotactic stimulus CCL20. Moreover IL-17A was expressed by macrophages infiltrating 
sarcoid tissue. Sarcoidosis is a systemic inflammatory disease characterized by noncaseating granulomas in various organs with pulmonary involvement in over $90 \%$ of patients (ATS 1999). These granulomas are compact, organized collections of macrophages and epithelioid cells, surrounded by and infiltrated with $\mathrm{T}$ lymphocytes, but the pathological processes that result in granulomatous inflammation are largely unknown. The accumulation in the lung of apparently oligoclonal IFN $\gamma$-producing $\mathrm{T}$ helper cells in sarcoidosis indicated an antigen-driven Th1 response (Rosen 2007; Zaba et al. 2010). Also because IL-17A has been implicated in the formation of a mycobacterial infection-induced granuloma in the lung (Curtis and Way 2009), we investigated Th17 cells by intracellular flow cytometry and immunohistochemistry in blood, BAL and bronchial mucosal biopsies from a cohort of newly diagnosed sarcoidosis patients and healthy controls. These studies provided evidence for the involvement of the Th17 lineage in sarcoidosis: IL-17A-expressing $\mathrm{T}$ cells were present in and around the granuloma and IL-22-expressing T cells were found in the subepithelial lamina propria in mucosal biopsies of sarcoidosis patients (Figure 4). This was accompanied by the presence of IL-17A ${ }^{+}$, IL-17A + IFN $\gamma^{+}$and IL-17A+IL-4+ memory $\mathrm{T}$ helper cells in BAL and by a significant increase in the proportions of these cells in the circulation (ten Berge et al. 2011).
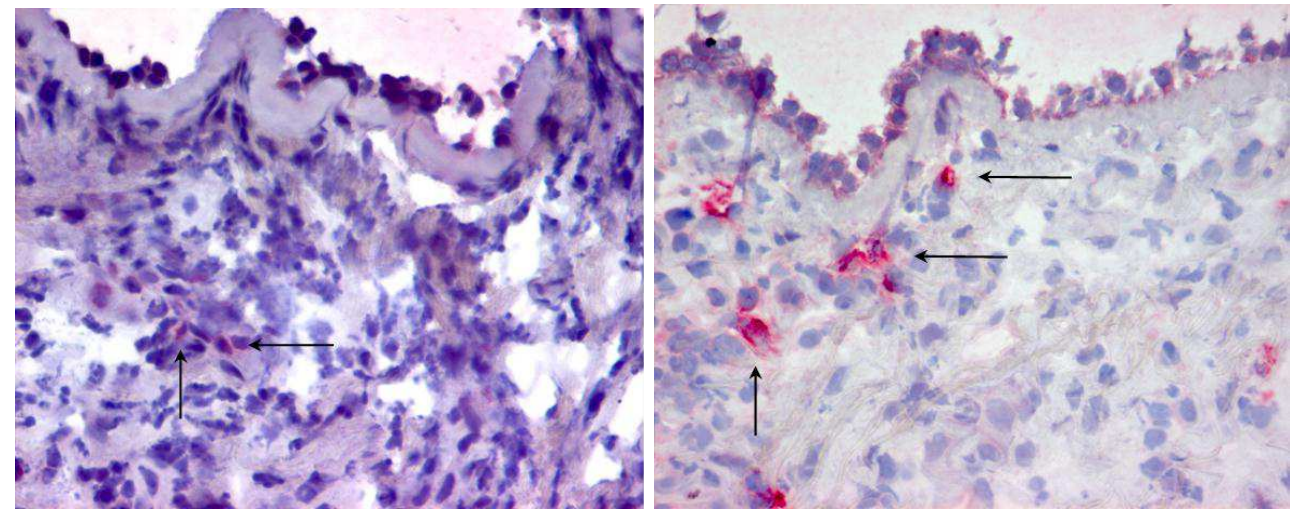

Fig. 4. IL-17A+ and IL-22+ cells in sarcoidosis lung biopsies containing granulomas.

Hematoxylin nucleus staining and IL-17A (left) and IL-22 (right) staining of lung mucosal frozen sections from a granuloma-containing sarcoidosis biopsy (40 x magnifications).

Arrows indicate IL-17A ${ }^{+}$cells as well as diffuse IL-17A staining in red (left) and IL-22 ${ }^{+}$cells as well as diffuse IL-22 staining in the epithelium in red (right).

\subsection{IL-17 in transplantation}

Organ transplantation is currently a valid treatment option for selected patients with endstage disease. Graft rejection is still the most severe complication following organ transplantation. In lung transplantation, episodes of acute rejection (AR) tend to lead to chronic rejection, which is the main cause of late graft loss and poor long-term survival (Lee, Christie, and Keshavjee 2010; Burton et al. 2007). The diagnosis of AR is based on clinical findings and/or histological confirmation in transbronchial biopsies (Vanaudenaerde et al. 2006). It has been shown that in addition to the frequency and severity of AR, also other risk factors such as ischemia-reperfusion injury (Lee, Christie, and Keshavjee 2010), gastro- 
oesophageal reflux (King et al. 2009), CMV pneumonitis and other infections (Valentine et al. 2009) are associated with an increased risk of chronic rejection. Chronic graft rejection, clinically known as BOS is defined as a progressive decline in lung function with other underlying conditions being absent (Estenne et al. 2002). More than $50 \%$ of the patients surviving five years after lung transplantation suffer from BOS (Christie et al. 2010).

Classically, graft rejection has been shown to be mediated by $\mathrm{CD}^{+}$and $\mathrm{CD} 8^{+} \mathrm{T}$ cells (Heeger 2003). Th1 cells were associated with graft rejection, whereas Th2 cells were considered to protect against rejection (Piccotti et al. 1997). Evidence is accumulating for an important role of IL-17 in allograft rejection, both in rodent models and humans. Prior to the first description of Th17 cells, IL-17 was implicated in the process of allograft rejection. Blocking IL-17 function in a rat cardiac allograft transplantation model increased graft survival significantly (Antonysamy et al. 1999). Around that same period, a number of reports highlighted the importance of IL-17 in the context of renal transplantation. Already in 1998 it was shown that IL-17 was detectable by immunofluorescent staining of acutely rejecting human renal transplant biopsies, but not in healthy kidneys or pre-transplant biopsies (Van Kooten et al. 1998). Moreover, elevated IL-17 mRNA and protein levels could be detected in renal biopsy specimens and urinary sediment from patients found to have subclinical rejection when compared with control samples without any evidence of rejections (Loong et al. 2002). Additionally, elevated IL-17 mRNA and protein levels were detectable as early as the second post-operative day in a rat renal allograft model and its appearance is followed by the local production of pro-inflammatory molecules known to be induced by IL-17 (Hsieh et al. 2001).

It is important to keep in mind that transplantation procedures themselves may have a direct effect on the cytokine profile within the graft. Following an organ harvest the ischemia-reperfusion injury results in the release of a number of inflammatory mediators. These mediators include some of the cytokines that are important in $\mathrm{T}$ cell differentiation such as TGF $\beta$ (Basile et al. 2001). A recent study demonstrated that factors released by human endothelial cells as a consequence of ischemia-reperfusion injury could enhance the production of both IL-17 and IFNY by CD4 ${ }^{+} \mathrm{T}$ cells (Rao, Tracey, and Pober 2007). These findings indicate that perioperative factors might result in increased Th17 activity within the graft.

\subsubsection{IL-17 in lung transplantation}

In lung transplantation, IL-17 has been implicated in ischemia reperfusion injury, acute rejection, infection and BOS (Bobadilla et al. 2008; Vanaudenaerde, De Vleeschauwer et al. 2008; Yoshida et al. 2006). At day 28 after lung transplantation, IL-17 mRNA levels were found to be elevated in the bronchoalveolar lavage (BAL) fluid from patients with acute rejection when compared with those without rejection. This difference disappeared at longer follow up (Vanaudenaerde et al. 2006). These increased IL-17 levels were associated with increased numbers of both BAL lymphocytes and neutrophils and correlated with the severity of rejection (Vanaudenaerde et al. 2006). However, such a correlation with severity of rejection could not be confirmed in another study even though this study did show increased numbers of IL-17 positive cells in endobronchial biopsies early after lung transplantation (Snell et al. 2007). These apparently conflicting results may be explained by differences in the time of sampling, suggesting that early events after transplantation may be critical for inducing IL-17 production or that patient selection is crucial (Shilling and 
Wilkes 2011). Additionally, patient heterogeneity may also cause conflicting results, e.g. by including both unilateral and bilateral transplant patients or by not discriminating between primary lung diseases.

Protein levels of IL- 6 and IL- $1 \beta$ and mRNA levels for TGF- $\beta$, IL-17, IL-23 and IL-8 in BAL fluid were increased in lung transplant recipients with BOS when compared to controls (Vanaudenaerde, Wuyts et al. 2008). CXCL8, a potent chemoattractant for neutrophils, has previously been associated with BOS, but it was unclear whether the presence of neutrophils was just a marker of general inflammation or a key mediator of obliterative bronchiolitis (McDyer 2007). Since IL-17 promotes neutrophil chemotaxis, the presence of neutrophils has been suggested to be secondary to a Th17-mediated alloimmune or autoimmune response (Shilling and Wilkes 2011). In a mouse model increased levels of IL-6 and IL-17 also correlated with tracheal obliteration, and blockade of IL-6 decreased both allograft fibrosis and IL-17 transcripts (Nakagiri et al. 2010). Increased neutrophilic inflammation of the airways with upregulation of IL-8 is common in the BAL of BOS patients. However, there are also many of these patients without considerable BAL neutrophilia despite the fact that they seem to be in an identical clinical condition with progressive decline in lung function, compatible with BOS. This may indicate the existence of different phenotypes within BOS with possible different treatment strategies. BAL neutrophilia might therefore be an important tool to select patients who might benefit from azithromycin treatment, since it has been demonstrated that azithromycin significantly reduces airway neutrophilia and CXCL8 in patients with BOS (Gottlieb et al. 2008).

Th17 cell responses may also trigger BOS by facilitating autoimmune responses, because autoantibodies against collagen type $\mathrm{V}$ have been described to be involved in lung allograft rejection (Burlingham et al. 2007). Immunohistochemical analysis indicated that collagen $\mathrm{V}$ becomes exposed in the lung matrix after ischemia-reperfusion injury in rat lung isografts and allografts (Yoshida et al. 2006), and that collagen V peptides are released in the BAL (Haque et al. 2002). Additionally, in humans it has been shown that pre-transplant patients who exhibit collagen $\mathrm{V}$ reactivity have an increased incidence of early graft dysfunction following lung transplantation (Bobadilla et al. 2008).

Recent observations in our own group indicate that not only in BOS but also in stable lung transplantation patients IL-17 and other Th17 cytokines might play a role. We found enhanced Th17 differentiation of peripheral blood mononuclear cells (PBMC) in a group of stable lung transplantation patients, compared with both healthy individuals and patients on the waiting list for a lung transplantation. The increase in the proportions of circulating Th17 cells was not linked to donor-specific haploreactivity. Interestingly, increased proportions of circulating IL- $17 \mathrm{~A}^{+} \mathrm{CD}^{+} \mathrm{T}$ cells co-expressing IFNY were found, indicating that specific Th17 subpopulations may have a functional role in stable lung transplantation patients (Paats et al., unpublished data).

\section{Therapeutic potential}

Accumulating evidence suggests that IL-17 and other cytokines involved in the Th17 pathway play an important role in the pathogenesis of various lung diseases. Interference with the activity of Th17 cells or the inflammatory mediators that either induce them (IL-1 $\beta$, IL-6, and IL-23), act in concert with IL-17 (TNFa and IL-1 $\beta$ ), or work downstream of IL-17 could be an effective treatment modality. One of these novel treatment modalities is cell blockade by monoclonal antibodies. Most antibody therapies have not yet been tested in 
lung pathology, which is remarkable because of the lung's continuous exposure to external triggers and pathogens. The risks of monoclonal antibody therapies must also be kept in mind. Adverse effects including infections, cancer and autoimmune disease are all issues that need consideration before antibody treatment can be introduced (Hansel et al. 2010).

The most direct way to control the biologic effects of Th17 cells would be to target production of their effector cytokines. Monoclonal antibodies against IL-17 or the IL-17R and a soluble IL-17R have been developed for clinical application. Administration of LY2439821, an anti-IL-17 monoclonal antibody, has been described in RA and improved signs and symptoms of the disease, without significant adverse events (Genovese et al. 2010). Additionally, it is promising that clinical trials with the fully human antibody, AIN457, in RA, psoriasis and noninfectious uveitis, show that targeting IL-17A interrupts inflammation and reduces disease activity (Hueber et al. 2010). Inhibitors of other products of Th17 cells such as IL-21 and IL-22 have not reached the clinical setting (Ma et al. 2008; Young et al. 2007). Another option might be to down-regulate IL-1 $\beta$, IL-6 and IL-23, the cytokines that induce Th17 differentiation. Targeting the IL-6R with a monoclonal antibody (e.g., tocilizumab, a humanized monoclonal antibody against the receptor) and neutralizing the IL-1R with an antagonist (e.g., anakinra, a recombinant human IL-1R antagonist) are two effective approaches to the treatment of rheumatoid arthritis and other autoimmune inflammatory diseases (Dinarello 2005; Yokota et al. 2005). A monoclonal antibody (ustekinumab) targeting the shared IL-12/IL-23 p40 subunit, blocks both Th1 and Th17 cells and was shown to be efficient in the treatment of psoriasis and Crohn's disease (Griffiths et al. 2010). IL-17 induces the production of IL-1 $\beta$ and TNFa. Antibodies, antagonists or receptor antagonists to IL-1 and TNFa are already in use for a range of autoimmune and chronic inflammatory conditions (Sutton et al. 2009). Unfortunately, recurrence of immunoinflammatory disease when treatment with TNFa inhibitors is discontinued is common. A combination of IL-17 and TNFa inhibitors, administered either simultaneously or sequentially, might be a good alternative to better control inflammation (Nadkarni, Mauri, and Ehrenstein 2007; Miossec, Korn, and Kuchroo 2009). Targeting intracellular signaling molecules or transcriptional factors involved in the activation of IL-17 production e. g. by small molecule inhibitors is an alternative approach for the development of new drugs. However, it is complicated by the fact that many of the signaling pathways are not unique to the IL-23-IL-17 axis and may also inhibit responses of other cell types involved in protective immunity (Mills 2008).

Non-selective blockade of the adaptive immune system by the use of steroids or cyclosporine seem ineffective in patients with severe asthma, COPD and CF (Barnes 2008; Vanaudenaerde et al. 2011). This is probably due to the reported steroid resistance of the Th17 cell-neutrophil axis (McKinley et al. 2008). Other medication capable of dampening the innate immune system might be an alternative way to interfere with the Th17 pathway. The best documented therapy for reducing IL-17-T cell-mediated neutrophilia is macrolide therapy, which is being used effectively in clinical practice in patients with $\mathrm{CF}$, asthma, COPD and BOS (Jaffe and Bush 2001; Seemungal et al. 2008). In addition, in vitro studies have shown that vitamin D inhibits Th17 cells (Mora, Iwata, and von Andrian 2008; Colin et al. 2010), hence vitamin D therapy might have potential in controlling Th17-mediated lung diseases. Clinical trials that could prove the importance of vitamin D in chronic lung diseases are currently in progress. Furthermore, other medication capable of interfering with the innate immune system, such as vitamin A or statins, merits attention (Vanaudenaerde et al. 2011). 


\section{Conclusions}

We still have much to learn about the phenotype, function and regulation of human Th17 cells. It is however clear that IL-17 and other Th17 associated cytokines play a central role in regulating diverse immune responses. With their potential to induce a pronounced neutrophilic inflammation, which is a common feature of many pulmonary inflammatory conditions, Th17 cells are subject of great research interest. Important to realize is that besides Th17 cells there are also other sources of IL-17, including CD8+ T cells, $\gamma \delta \mathrm{T}$ cells, NK $\mathrm{T}$ cells, and LTi cells. Depending on the timing, the tissue, and the local microenvironment, IL-17 secreting cells appear to be able to play both beneficial and detrimental roles in lung immunity and disease. The exact balance of these roles during the processes of many autoimmune and infectious diseases is however not fully understood yet. Therefore, the challenge lies in uncovering strategies to maximize the protective effect of IL-17 producing cells while simultaneously preventing these cells from causing immune-mediated host damage. At present, therapies that modulate the Th17 cell pathway are being tested in the clinic with promising results.

\section{Acknowledgement}

We thank Bernt van den Blink, Alex Kleinjan and Ingrid Bergen (Erasmus MC Rotterdam) for their assistance and stimulating discussions.

\section{References}

Abdulahad, W. H., C. A. Stegeman, P. C. Limburg, and C. G. Kallenberg. 2008. Skewed distribution of Th17 lymphocytes in patients with Wegener's granulomatosis in remission. Arthritis Rheum 58 (7):2196-205.

Acosta-Rodriguez, E. V., G. Napolitani, A. Lanzavecchia, and F. Sallusto. 2007. Interleukins 1beta and 6 but not transforming growth factor-beta are essential for the differentiation of interleukin 17-producing human T helper cells. Nat Immunol 8 (9):942-9.

Acosta-Rodriguez, E. V., L. Rivino, J. Geginat, D. Jarrossay, M. Gattorno, A. Lanzavecchia, F. Sallusto, and G. Napolitani. 2007. Surface phenotype and antigenic specificity of human interleukin 17-producing T helper memory cells. Nat Immunol 8 (6):639-46.

Akira, S., S. Uematsu, and O. Takeuchi. 2006. Pathogen recognition and innate immunity. Cell 124 (4):783-801.

Al-Ramli, W., D. Prefontaine, F. Chouiali, J. G. Martin, R. Olivenstein, C. Lemiere, and Q. Hamid. 2009. T(H)17-associated cytokines (IL-17A and IL-17F) in severe asthma. J Allergy Clin Immunol 123 (5):1185-7.

Anderson, G. P. 2008. Endotyping asthma: new insights into key pathogenic mechanisms in a complex, heterogeneous disease. Lancet 372 (9643):1107-19.

Annunziato, F., L. Cosmi, V. Santarlasci, L. Maggi, F. Liotta, B. Mazzinghi, E. Parente, L. Fili, S. Ferri, F. Frosali, F. Giudici, P. Romagnani, P. Parronchi, F. Tonelli, E. Maggi, and S. Romagnani. 2007. Phenotypic and functional features of human Th17 cells. J Exp Med 204 (8):1849-61. 
Antonysamy, M. A., W. C. Fanslow, F. Fu, W. Li, S. Qian, A. B. Troutt, and A. W. Thomson. 1999. Evidence for a role of IL-17 in alloimmunity: a novel IL-17 antagonist promotes heart graft survival. Transplant Proc 31 (1-2):93.

Arican, O., M. Aral, S. Sasmaz, and P. Ciragil. 2005. Serum levels of TNF-alpha, IFN-gamma, IL-6, IL-8, IL-12, IL-17, and IL-18 in patients with active psoriasis and correlation with disease severity. Mediators Inflamm 2005 (5):273-9.

ATS, ERS, WASOG. 1999. Statement on sarcoidosis. Joint Statement of the American Thoracic Society (ATS), the European Respiratory Society (ERS) and the World Association of Sarcoidosis and Other Granulomatous Disorders (WASOG) adopted by the ATS Board of Directors and by the ERS Executive Committee, February 1999. Am J Respir Crit Care Med 160 (2):736-55.

Aujla, S. J., Y. R. Chan, M. Zheng, M. Fei, D. J. Askew, D. A. Pociask, T. A. Reinhart, F. McAllister, J. Edeal, K. Gaus, S. Husain, J. L. Kreindler, P. J. Dubin, J. M. Pilewski, M. M. Myerburg, C. A. Mason, Y. Iwakura, and J. K. Kolls. 2008. IL-22 mediates mucosal host defense against Gram-negative bacterial pneumonia. Nat Med 14 (3):275-81.

Aujla, S. J., P. J. Dubin, and J. K. Kolls. 2007. Th17 cells and mucosal host defense. Semin Immunol 19 (6):377-82.

Barczyk, A., W. Pierzchala, and E. Sozanska. 2003. Interleukin-17 in sputum correlates with airway hyperresponsiveness to methacholine. Respir Med 97 (6):726-33.

Barnes, P. J. 2000. Chronic obstructive pulmonary disease. N Engl J Med 343 (4):269-80.

2008. Immunology of asthma and chronic obstructive pulmonary disease. Nat Rev Immunol 8 (3):183-92.

Basile, D. P., D. Donohoe, K. Roethe, and J. L. Osborn. 2001. Renal ischemic injury results in permanent damage to peritubular capillaries and influences long-term function. Am J Physiol Renal Physiol 281 (5):F887-99.

Bettelli, E., M. Oukka, and V. K. Kuchroo. 2007. T(H)-17 cells in the circle of immunity and autoimmunity. Nat Immunol 8 (4):345-50.

Bluestone, J. A., C. R. Mackay, J. J. O'Shea, and B. Stockinger. 2009. The functional plasticity of T cell subsets. Nat Rev Immunol 9 (11):811-6.

Bobadilla, J. L., R. B. Love, E. Jankowska-Gan, Q. Xu, L. D. Haynes, R. K. Braun, M. S. Hayney, A. Munoz del Rio, K. Meyer, D. S. Greenspan, J. Torrealba, K. M. Heidler, O. W. Cummings, T. Iwata, D. Brand, R. Presson, W. J. Burlingham, and D. S. Wilkes. 2008. Th-17, monokines, collagen type $\mathrm{V}$, and primary graft dysfunction in lung transplantation. Am J Respir Crit Care Med 177 (6):660-8.

Boniface, K., K. S. Bak-Jensen, Y. Li, W. M. Blumenschein, M. J. McGeachy, T. K. McClanahan, B. S. McKenzie, R. A. Kastelein, D. J. Cua, and R. de Waal Malefyt. 2009. Prostaglandin E2 regulates Th17 cell differentiation and function through cyclic AMP and EP2/EP4 receptor signaling. J Exp Med 206 (3):535-48.

Braun, R. K., A. Martin, S. Shah, M. Iwashima, M. Medina, K. Byrne, P. Sethupathi, C. H. Wigfield, D. D. Brand, and R. B. Love. 2010. Inhibition of bleomycin-induced pulmonary fibrosis through pre-treatment with collagen type V. J Heart Lung Transplant 29 (8):873-80.

Bullens, D. M., E. Truyen, L. Coteur, E. Dilissen, P. W. Hellings, L. J. Dupont, and J. L. Ceuppens. 2006. IL-17 mRNA in sputum of asthmatic patients: linking T cell driven inflammation and granulocytic influx? Respir Res 7:135. 
Burlingham, W. J., R. B. Love, E. Jankowska-Gan, L. D. Haynes, Q. Xu, J. L. Bobadilla, K. C. Meyer, M. S. Hayney, R. K. Braun, D. S. Greenspan, B. Gopalakrishnan, J. Cai, D. D. Brand, S. Yoshida, O. W. Cummings, and D. S. Wilkes. 2007. IL-17-dependent cellular immunity to collagen type $\mathrm{V}$ predisposes to obliterative bronchiolitis in human lung transplants. J Clin Invest 117 (11):3498-506.

Burton, C. M., J. Carlsen, J. Mortensen, C. B. Andersen, N. Milman, and M. Iversen. 2007. Long-term survival after lung transplantation depends on development and severity of bronchiolitis obliterans syndrome. J Heart Lung Transplant 26 (7):681-6.

Calikoglu, M., G. Sahin, A. Unlu, C. Ozturk, L. Tamer, B. Ercan, A. Kanik, and U. Atik. 2004. Leptin and TNF-alpha levels in patients with chronic obstructive pulmonary disease and their relationship to nutritional parameters. Respiration 71 (1):45-50.

Cella, M., A. Fuchs, W. Vermi, F. Facchetti, K. Otero, J. K. Lennerz, J. M. Doherty, J. C. Mills, and M. Colonna. 2009. A human natural killer cell subset provides an innate source of IL-22 for mucosal immunity. Nature 457 (7230):722-5.

Chang, Y., J. Nadigel, N. Boulais, J. Bourbeau, F. Maltais, D. H. Eidelman, and Q. Hamid. 2011. CD8 positive T cells express IL-17 in patients with chronic obstructive pulmonary disease. Respir Res 12:43.

Chen, Z., and J. J. O'Shea. 2008. Regulation of IL-17 production in human lymphocytes. Cytokine 41 (2):71-8.

Chen, Z., C. M. Tato, L. Muul, A. Laurence, and J. J. O'Shea. 2007. Distinct regulation of interleukin-17 in human T helper lymphocytes. Arthritis Rheum 56 (9):2936-46.

Christie, J. D., L. B. Edwards, A. Y. Kucheryavaya, P. Aurora, F. Dobbels, R. Kirk, A. O. Rahmel, J. Stehlik, and M. I. Hertz. 2010. The Registry of the International Society for Heart and Lung Transplantation: twenty-seventh official adult lung and heartlung transplant report--2010. J Heart Lung Transplant 29 (10):1104-18.

Colin, E. M., P. S. Asmawidjaja, J. P. van Hamburg, A. M. Mus, M. van Driel, J. M. Hazes, J. P. van Leeuwen, and E. Lubberts. 2010. 1,25-dihydroxyvitamin D3 modulates Th17 polarization and interleukin-22 expression by memory $\mathrm{T}$ cells from patients with early rheumatoid arthritis. Arthritis Rheum 62 (1):132-42.

Cosmi, L., R. De Palma, V. Santarlasci, L. Maggi, M. Capone, F. Frosali, G. Rodolico, V. Querci, G. Abbate, R. Angeli, L. Berrino, M. Fambrini, M. Caproni, F. Tonelli, E. Lazzeri, P. Parronchi, F. Liotta, E. Maggi, S. Romagnani, and F. Annunziato. 2008. Human interleukin 17-producing cells originate from a CD161+CD4+ T cell precursor. J Exp Med 205 (8):1903-16.

Cosmi, L., F. Liotta, E. Maggi, S. Romagnani, and F. Annunziato. 2011. Th17 cells: new players in asthma pathogenesis. Allergy 66 (8):989-98.

Coury, F., N. Annels, A. Rivollier, S. Olsson, A. Santoro, C. Speziani, O. Azocar, M. Flacher, S. Djebali, J. Tebib, M. Brytting, R. M. Egeler, C. Rabourdin-Combe, J. I. Henter, M. Arico, and C. Delprat. 2008. Langerhans cell histiocytosis reveals a new IL-17Adependent pathway of dendritic cell fusion. Nat Med 14 (1):81-7.

Crome, S. Q., A. Y. Wang, C. Y. Kang, and M. K. Levings. 2009. The role of retinoic acidrelated orphan receptor variant 2 and IL-17 in the development and function of human CD4+ T cells. Eur J Immunol 39 (6):1480-93.

Crome, S. Q., A. Y. Wang, and M. K. Levings. 2010. Translational mini-review series on Th17 cells: function and regulation of human T helper 17 cells in health and disease. Clin Exp Immunol 159 (2):109-19. 
Crotty, S. 2011. Follicular helper CD4 T cells (TFH). Annu Rev Immunol 29:621-63.

Cua, D. J., and C. M. Tato. 2010. Innate IL-17-producing cells: the sentinels of the immune system. Nat Rev Immunol 10 (7):479-89.

Curtis, J. L., C. M. Freeman, and J. C. Hogg. 2007. The immunopathogenesis of chronic obstructive pulmonary disease: insights from recent research. Proc Am Thorac Soc 4 (7):512-21.

Curtis, M. M., and S. S. Way. 2009. Interleukin-17 in host defence against bacterial, mycobacterial and fungal pathogens. Immunology 126 (2):177-85.

Di Stefano, A., G. Caramori, I. Gnemmi, M. Contoli, C. Vicari, A. Capelli, F. Magno, S. E. D'Anna, A. Zanini, P. Brun, P. Casolari, K. F. Chung, P. J. Barnes, A. Papi, I. Adcock, and B. Balbi. 2009. T helper type 17-related cytokine expression is increased in the bronchial mucosa of stable chronic obstructive pulmonary disease patients. Clin Exp Immunol 157 (2):316-24.

Dinarello, C. A. 2005. Blocking IL-1 in systemic inflammation. J Exp Med 201 (9):1355-9.

Doe, C., M. Bafadhel, S. Siddiqui, D. Desai, V. Mistry, P. Rugman, M. McCormick, J. Woods, R. May, M. A. Sleeman, I. K. Anderson, and C. E. Brightling. 2010. Expression of the T helper 17-associated cytokines IL-17A and IL-17F in asthma and COPD. Chest 138 (5):1140-7.

Dong, C. 2008. TH17 cells in development: an updated view of their molecular identity and genetic programming. Nat Rev Immunol 8 (5):337-48.

Dubin, P. J., and J. K. Kolls. 2007. IL-23 mediates inflammatory responses to mucoid Pseudomonas aeruginosa lung infection in mice. Am J Physiol Lung Cell Mol Physiol 292 (2):L519-28.

Duhen, T., R. Geiger, D. Jarrossay, A. Lanzavecchia, and F. Sallusto. 2009. Production of interleukin 22 but not interleukin 17 by a subset of human skin-homing memory $\mathrm{T}$ cells. Nat Immunol 10 (8):857-63.

Eberl, G., S. Marmon, M. J. Sunshine, P. D. Rennert, Y. Choi, and D. R. Littman. 2004. An essential function for the nuclear receptor RORgamma(t) in the generation of fetal lymphoid tissue inducer cells. Nat Immunol 5 (1):64-73.

Elias, K. M., A. Laurence, T. S. Davidson, G. Stephens, Y. Kanno, E. M. Shevach, and J. J. O'Shea. 2008. Retinoic acid inhibits Th17 polarization and enhances FoxP3 expression through a Stat-3/Stat-5 independent signaling pathway. Blood 111 (3):1013-20.

Estenne, M., J. R. Maurer, A. Boehler, J. J. Egan, A. Frost, M. Hertz, G. B. Mallory, G. I. Snell, and S. Yousem. 2002. Bronchiolitis obliterans syndrome 2001: an update of the diagnostic criteria. J Heart Lung Transplant 21 (3):297-310.

Evans, H. G., N. J. Gullick, S. Kelly, C. Pitzalis, G. M. Lord, B. W. Kirkham, and L. S. Taams. 2009. In vivo activated monocytes from the site of inflammation in humans specifically promote Th17 responses. Proc Natl Acad Sci U S A 106 (15):6232-7.

Facco, M., A. Cabrelle, A. Teramo, V. Olivieri, M. Gnoato, S. Teolato, E. Ave, C. Gattazzo, G. P. Fadini, F. Calabrese, G. Semenzato, and C. Agostini. 2011. Sarcoidosis is a Th1/Th17 multisystem disorder. Thorax 66 (2):144-50.

Fedele, G., M. Nasso, F. Spensieri, R. Palazzo, L. Frasca, M. Watanabe, and C. M. Ausiello. 2008. Lipopolysaccharides from Bordetella pertussis and Bordetella parapertussis differently modulate human dendritic cell functions resulting in divergent prevalence of Th17-polarized responses. J Immunol 181 (1):208-16. 
Feghali-Bostwick, C. A., A. S. Gadgil, L. E. Otterbein, J. M. Pilewski, M. W. Stoner, E. Csizmadia, Y. Zhang, F. C. Sciurba, and S. R. Duncan. 2008. Autoantibodies in patients with chronic obstructive pulmonary disease. Am J Respir Crit Care Med 177 (2):156-63.

Feldmann, M., F. M. Brennan, B. M. Foxwell, and R. N. Maini. 2001. The role of TNF alpha and IL-1 in rheumatoid arthritis. Curr Dir Autoimmun 3:188-99.

Ferretti, S., O. Bonneau, G. R. Dubois, C. E. Jones, and A. Trifilieff. 2003. IL-17, produced by lymphocytes and neutrophils, is necessary for lipopolysaccharide-induced airway neutrophilia: IL-15 as a possible trigger. J Immunol 170 (4):2106-12.

Fossiez, F., O. Djossou, P. Chomarat, L. Flores-Romo, S. Ait-Yahia, C. Maat, J. J. Pin, P. Garrone, E. Garcia, S. Saeland, D. Blanchard, C. Gaillard, B. Das Mahapatra, E. Rouvier, P. Golstein, J. Banchereau, and S. Lebecque. 1996. T cell interleukin-17 induces stromal cells to produce proinflammatory and hematopoietic cytokines. $J$ Exp Med 183 (6):2593-603.

Fujino, S., A. Andoh, S. Bamba, A. Ogawa, K. Hata, Y. Araki, T. Bamba, and Y. Fujiyama. 2003. Increased expression of interleukin 17 in inflammatory bowel disease. Gut 52 (1):65-70.

Genovese, M. C., F. Van den Bosch, S. A. Roberson, S. Bojin, I. M. Biagini, P. Ryan, and J. Sloan-Lancaster. 2010. LY2439821, a humanized anti-interleukin-17 monoclonal antibody, in the treatment of patients with rheumatoid arthritis: A phase I randomized, double-blind, placebo-controlled, proof-of-concept study. Arthritis Rheum 62 (4):929-39.

Godfrey, D. I., H. R. MacDonald, M. Kronenberg, M. J. Smyth, and L. Van Kaer. 2004. NKT cells: what's in a name? Nat Rev Immunol 4 (3):231-7.

Gottlieb, J., J. Szangolies, T. Koehnlein, H. Golpon, A. Simon, and T. Welte. 2008. Long-term azithromycin for bronchiolitis obliterans syndrome after lung transplantation. Transplantation 85 (1):36-41.

Griffiths, C. E., B. E. Strober, P. van de Kerkhof, V. Ho, R. Fidelus-Gort, N. Yeilding, C. Guzzo, Y. Xia, B. Zhou, S. Li, L. T. Dooley, N. H. Goldstein, A. Menter, and Accept Study Group. 2010. Comparison of ustekinumab and etanercept for moderate-tosevere psoriasis. N Engl J Med 362 (2):118-28.

Hacievliyagil, S. S., H. Gunen, L. C. Mutlu, A. B. Karabulut, and I. Temel. 2006. Association between cytokines in induced sputum and severity of chronic obstructive pulmonary disease. Respir Med 100 (5):846-54.

Hansel, T. T., H. Kropshofer, T. Singer, J. A. Mitchell, and A. J. George. 2010. The safety and side effects of monoclonal antibodies. Nat Rev Drug Discov 9 (4):325-38.

Happel, K. I., P. J. Dubin, M. Zheng, N. Ghilardi, C. Lockhart, L. J. Quinton, A. R. Odden, J. E. Shellito, G. J. Bagby, S. Nelson, and J. K. Kolls. 2005. Divergent roles of IL-23 and IL-12 in host defense against Klebsiella pneumoniae. J Exp Med 202 (6):761-9.

Happel, K. I., M. Zheng, E. Young, L. J. Quinton, E. Lockhart, A. J. Ramsay, J. E. Shellito, J. R. Schurr, G. J. Bagby, S. Nelson, and J. K. Kolls. 2003. Cutting edge: roles of Toll-like receptor 4 and IL-23 in IL-17 expression in response to Klebsiella pneumoniae infection. J Immunol 170 (9):4432-6.

Haque, M. A., T. Mizobuchi, K. Yasufuku, T. Fujisawa, R. R. Brutkiewicz, Y. Zheng, K. Woods, G. N. Smith, O. W. Cummings, K. M. Heidler, J. S. Blum, and D. S. Wilkes. 2002. Evidence for immune responses to a self-antigen in lung transplantation: role 
of type $\mathrm{V}$ collagen-specific $\mathrm{T}$ cells in the pathogenesis of lung allograft rejection. $J$ Immunol 169 (3):1542-9.

Harrington, L. E., R. D. Hatton, P. R. Mangan, H. Turner, T. L. Murphy, K. M. Murphy, and C. T. Weaver. 2005. Interleukin 17-producing CD4+ effector T cells develop via a lineage distinct from the T helper type 1 and 2 lineages. Nat Immunol 6 (11):1123-32.

Harrison, O. J., J. Foley, B. J. Bolognese, E. Long, 3rd, P. L. Podolin, and P. T. Walsh. 2008. Airway infiltration of CD4+ CCR6+ Th17 type cells associated with chronic cigarette smoke induced airspace enlargement. Immunol Lett 121 (1):13-21.

Hashimoto, K., J. E. Durbin, W. Zhou, R. D. Collins, S. B. Ho, J. K. Kolls, P. J. Dubin, J. R. Sheller, K. Goleniewska, J. F. O'Neal, S. J. Olson, D. Mitchell, B. S. Graham, and R. S. Peebles, Jr. 2005. Respiratory syncytial virus infection in the absence of STAT 1 results in airway dysfunction, airway mucus, and augmented IL-17 levels. J Allergy Clin Immunol 116 (3):550-7.

Hayashi, N., T. Yoshimoto, K. Izuhara, K. Matsui, T. Tanaka, and K. Nakanishi. 2007. T helper 1 cells stimulated with ovalbumin and IL-18 induce airway hyperresponsiveness and lung fibrosis by IFN-gamma and IL-13 production. Proc Natl Acad Sci U S A 104 (37):14765-70.

Heeger, P. S. 2003. T-cell allorecognition and transplant rejection: a summary and update. Am J Transplant 3 (5):525-33.

Higgins, S. C., A. G. Jarnicki, E. C. Lavelle, and K. H. Mills. 2006. TLR4 mediates vaccineinduced protective cellular immunity to Bordetella pertussis: role of IL-17producing T cells. J Immunol 177 (11):7980-9.

Hill, H. R., H. D. Ochs, P. G. Quie, R. A. Clark, H. F. Pabst, S. J. Klebanoff, and R. J. Wedgwood. 1974. Defect in neutrophil granulocyte chemotaxis in Job's syndrome of recurrent "cold" staphylococcal abscesses. Lancet 2 (7881):617-9.

Hizawa, N., M. Kawaguchi, S. K. Huang, and M. Nishimura. 2006. Role of interleukin-17F in chronic inflammatory and allergic lung disease. Clin Exp Allergy 36 (9):1109-14.

Hogg, J. C. 2004. Pathophysiology of airflow limitation in chronic obstructive pulmonary disease. Lancet 364 (9435):709-21.

Hogg, J. C., F. Chu, S. Utokaparch, R. Woods, W. M. Elliott, L. Buzatu, R. M. Cherniack, R. M. Rogers, F. C. Sciurba, H. O. Coxson, and P. D. Pare. 2004. The nature of smallairway obstruction in chronic obstructive pulmonary disease. N Engl J Med 350 (26):2645-53.

Hsieh, H. G., C. C. Loong, W. Y. Lui, A. Chen, and C. Y. Lin. 2001. IL-17 expression as a possible predictive parameter for subclinical renal allograft rejection. Transpl Int 14 (5):287-98.

Hueber, W., D. D. Patel, T. Dryja, A. M. Wright, I. Koroleva, G. Bruin, C. Antoni, Z. Draelos, M. H. Gold, Group Psoriasis Study, P. Durez, P. P. Tak, J. J. Gomez-Reino, Group Rheumatoid Arthritis Study, C. S. Foster, R. Y. Kim, C. M. Samson, N. S. Falk, D. S. Chu, D. Callanan, Q. D. Nguyen, Group Uveitis Study, K. Rose, A. Haider, and F. Di Padova. 2010. Effects of AIN457, a fully human antibody to interleukin-17A, on psoriasis, rheumatoid arthritis, and uveitis. Sci Transl Med 2 (52):52ra72.

Ito, Y., T. Usui, S. Kobayashi, M. Iguchi-Hashimoto, H. Ito, H. Yoshitomi, T. Nakamura, M. Shimizu, D. Kawabata, N. Yukawa, M. Hashimoto, N. Sakaguchi, S. Sakaguchi, H. Yoshifuji, T. Nojima, K. Ohmura, T. Fujii, and T. Mimori. 2009. Gamma/delta T 
cells are the predominant source of interleukin-17 in affected joints in collageninduced arthritis, but not in rheumatoid arthritis. Arthritis Rheum 60 (8):2294-303.

Ivanov, II, B. S. McKenzie, L. Zhou, C. E. Tadokoro, A. Lepelley, J. J. Lafaille, D. J. Cua, and D. R. Littman. 2006. The orphan nuclear receptor RORgammat directs the differentiation program of proinflammatory IL-17+ T helper cells. Cell 126 (6):112133.

Jaffe, A., and A. Bush. 2001. Anti-inflammatory effects of macrolides in lung disease. Pediatr Pulmonol 31 (6):464-73.

Joshi, A. D., D. J. Fong, S. R. Oak, G. Trujillo, K. R. Flaherty, F. J. Martinez, and C. M. Hogaboam. 2009. Interleukin-17-mediated immunopathogenesis in experimental hypersensitivity pneumonitis. Am J Respir Crit Care Med 179 (8):705-16.

Khader, S. A., G. K. Bell, J. E. Pearl, J. J. Fountain, J. Rangel-Moreno, G. E. Cilley, F. Shen, S. M. Eaton, S. L. Gaffen, S. L. Swain, R. M. Locksley, L. Haynes, T. D. Randall, and A. M. Cooper. 2007. IL-23 and IL-17 in the establishment of protective pulmonary CD4+ $\mathrm{T}$ cell responses after vaccination and during Mycobacterium tuberculosis challenge. Nat Immunol 8 (4):369-77.

King, B. J., H. Iyer, A. A. Leidi, and M. R. Carby. 2009. Gastroesophageal reflux in bronchiolitis obliterans syndrome: a new perspective. J Heart Lung Transplant 28 (9):870-5.

Kolls, J. K., and A. Linden. 2004. Interleukin-17 family members and inflammation. Immunity 21 (4):467-76.

Kondo, T., H. Takata, F. Matsuki, and M. Takiguchi. 2009. Cutting edge: Phenotypic characterization and differentiation of human CD8+ T cells producing IL-17. J Immunol 182 (4):1794-8.

Kotake, S., N. Udagawa, N. Takahashi, K. Matsuzaki, K. Itoh, S. Ishiyama, S. Saito, K. Inoue, N. Kamatani, M. T. Gillespie, T. J. Martin, and T. Suda. 1999. IL-17 in synovial fluids from patients with rheumatoid arthritis is a potent stimulator of osteoclastogenesis. J Clin Invest 103 (9):1345-52.

Kryczek, I., A. T. Bruce, J. E. Gudjonsson, A. Johnston, A. Aphale, L. Vatan, W. Szeliga, Y. Wang, Y. Liu, T. H. Welling, J. T. Elder, and W. Zou. 2008. Induction of IL-17+ T cell trafficking and development by IFN-gamma: mechanism and pathological relevance in psoriasis. J Immunol 181 (7):4733-41.

Kurasawa, K., K. Hirose, H. Sano, H. Endo, H. Shinkai, Y. Nawata, K. Takabayashi, and I. Iwamoto. 2000. Increased interleukin-17 production in patients with systemic sclerosis. Arthritis Rheum 43 (11):2455-63.

Laan, M., Z. H. Cui, H. Hoshino, J. Lotvall, M. Sjostrand, D. C. Gruenert, B. E. Skoogh, and A. Linden. 1999. Neutrophil recruitment by human IL-17 via C-X-C chemokine release in the airways. J Immunol 162 (4):2347-52.

Lamblin, C., P. Gosset, I. Tillie-Leblond, F. Saulnier, C. H. Marquette, B. Wallaert, and A. B. Tonnel. 1998. Bronchial neutrophilia in patients with noninfectious status asthmaticus. Am J Respir Crit Care Med 157 (2):394-402.

Lee, J. C., J. D. Christie, and S. Keshavjee. 2010. Primary graft dysfunction: definition, risk factors, short- and long-term outcomes. Semin Respir Crit Care Med 31 (2):161-71.

Loong, C. C., H. G. Hsieh, W. Y. Lui, A. Chen, and C. Y. Lin. 2002. Evidence for the early involvement of interleukin 17 in human and experimental renal allograft rejection. $J$ Pathol 197 (3):322-32. 
Louis, R., L. C. Lau, A. O. Bron, A. C. Roldaan, M. Radermecker, and R. Djukanovic. 2000. The relationship between airways inflammation and asthma severity. Am J Respir Crit Care Med 161 (1):9-16.

Ma, C. S., S. Suryani, D. T. Avery, A. Chan, R. Nanan, B. Santner-Nanan, E. K. Deenick, and S. G. Tangye. 2009. Early commitment of naive human CD4(+) T cells to the T follicular helper $(\mathrm{T}(\mathrm{FH}))$ cell lineage is induced by IL-12. Immunol Cell Biol 87 (8):590-600.

Ma, H. L., S. Liang, J. Li, L. Napierata, T. Brown, S. Benoit, M. Senices, D. Gill, K. DunussiJoannopoulos, M. Collins, C. Nickerson-Nutter, L. A. Fouser, and D. A. Young. 2008. IL-22 is required for Th17 cell-mediated pathology in a mouse model of psoriasis-like skin inflammation. J Clin Invest 118 (2):597-607.

Maertzdorf, J., A. D. Osterhaus, and G. M. Verjans. 2002. IL-17 expression in human herpetic stromal keratitis: modulatory effects on chemokine production by corneal fibroblasts. J Immunol 169 (10):5897-903.

Malley, R., A. Srivastava, M. Lipsitch, C. M. Thompson, C. Watkins, A. Tzianabos, and P. W. Anderson. 2006. Antibody-independent, interleukin-17A-mediated, cross-serotype immunity to pneumococci in mice immunized intranasally with the cell wall polysaccharide. Infect Immun 74 (4):2187-95.

Manel, N., D. Unutmaz, and D. R. Littman. 2008. The differentiation of human T(H)-17 cells requires transforming growth factor-beta and induction of the nuclear receptor RORgammat. Nat Immunol 9 (6):641-9.

Mantel, P. Y., H. Kuipers, O. Boyman, C. Rhyner, N. Ouaked, B. Ruckert, C. Karagiannidis, B. N. Lambrecht, R. W. Hendriks, R. Crameri, C. A. Akdis, K. Blaser, and C. B. Schmidt-Weber. 2007. GATA3-driven Th2 responses inhibit TGF-beta1-induced FOXP3 expression and the formation of regulatory T cells. PLoS Biol 5 (12):e329.

McAllister, F., A. Henry, J. L. Kreindler, P. J. Dubin, L. Ulrich, C. Steele, J. D. Finder, J. M. Pilewski, B. M. Carreno, S. J. Goldman, J. Pirhonen, and J. K. Kolls. 2005. Role of IL17A, IL-17F, and the IL-17 receptor in regulating growth-related oncogene-alpha and granulocyte colony-stimulating factor in bronchial epithelium: implications for airway inflammation in cystic fibrosis. J Immunol 175 (1):404-12.

McDyer, J. F. 2007. Human and murine obliterative bronchiolitis in transplant. Proc Am Thorac Soc 4 (1):37-43.

McGeachy, M. J., K. S. Bak-Jensen, Y. Chen, C. M. Tato, W. Blumenschein, T. McClanahan, and D. J. Cua. 2007. TGF-beta and IL-6 drive the production of IL-17 and IL-10 by T cells and restrain T(H)-17 cell-mediated pathology. Nat Immunol 8 (12):1390-7.

McKinley, L., J. F. Alcorn, A. Peterson, R. B. Dupont, S. Kapadia, A. Logar, A. Henry, C. G. Irvin, J. D. Piganelli, A. Ray, and J. K. Kolls. 2008. TH17 cells mediate steroidresistant airway inflammation and airway hyperresponsiveness in mice. J Immunol 181 (6):4089-97.

Melgert, B. N., W. Timens, H. A. Kerstjens, M. Geerlings, M. A. Luinge, J. P. Schouten, D. S. Postma, and M. N. Hylkema. 2007. Effects of 4 months of smoking in mice with ovalbumin-induced airway inflammation. Clin Exp Allergy 37 (12):1798-808.

Michel, M. L., A. C. Keller, C. Paget, M. Fujio, F. Trottein, P. B. Savage, C. H. Wong, E. Schneider, M. Dy, and M. C. Leite-de-Moraes. 2007. Identification of an IL-17producing NK1.1(neg) iNKT cell population involved in airway neutrophilia. J Exp Med 204 (5):995-1001. 
Michel, M. L., D. Mendes-da-Cruz, A. C. Keller, M. Lochner, E. Schneider, M. Dy, G. Eberl, and M. C. Leite-de-Moraes. 2008. Critical role of ROR-gammat in a new thymic pathway leading to IL-17-producing invariant NKT cell differentiation. Proc Natl Acad Sci U S A 105 (50):19845-50.

Mills, K. H. 2008. Induction, function and regulation of IL-17-producing T cells. Eur J Immunol 38 (10):2636-49.

Milner, J. D., J. M. Brenchley, A. Laurence, A. F. Freeman, B. J. Hill, K. M. Elias, Y. Kanno, C. Spalding, H. Z. Elloumi, M. L. Paulson, J. Davis, A. Hsu, A. I. Asher, J. O'Shea, S. M. Holland, W. E. Paul, and D. C. Douek. 2008. Impaired T(H)17 cell differentiation in subjects with autosomal dominant hyper-IgE syndrome. Nature 452 (7188):773-6.

Miossec, P., T. Korn, and V. K. Kuchroo. 2009. Interleukin-17 and type 17 helper T cells. $N$ Engl J Med 361 (9):888-98.

Molet, S., Q. Hamid, F. Davoine, E. Nutku, R. Taha, N. Page, R. Olivenstein, J. Elias, and J. Chakir. 2001. IL-17 is increased in asthmatic airways and induces human bronchial fibroblasts to produce cytokines. J Allergy Clin Immunol 108 (3):430-8.

Mora, J. R., M. Iwata, and U. H. von Andrian. 2008. Vitamin effects on the immune system: vitamins A and D take centre stage. Nat Rev Immunol 8 (9):685-98.

Mosmann, T. R., and R. L. Coffman. 1989. TH1 and TH2 cells: different patterns of lymphokine secretion lead to different functional properties. Annu Rev Immunol 7:145-73.

Motz, G. T., B. L. Eppert, S. C. Wesselkamper, J. L. Flury, and M. T. Borchers. 2010. Chronic cigarette smoke exposure generates pathogenic T cells capable of driving COPDlike disease in Rag2-/- mice. Am J Respir Crit Care Med 181 (11):1223-33.

Murphy, D. M., I. A. Forrest, P. A. Corris, G. E. Johnson, T. Small, D. Jones, A. J. Fisher, J. J. Egan, T. E. Cawston, C. Ward, and J. L. Lordan. 2008. Simvastatin attenuates release of neutrophilic and remodeling factors from primary bronchial epithelial cells derived from stable lung transplant recipients. Am J Physiol Lung Cell Mol Physiol 294 (3):L592-9.

Nadkarni, S., C. Mauri, and M. R. Ehrenstein. 2007. Anti-TNF-alpha therapy induces a distinct regulatory $\mathrm{T}$ cell population in patients with rheumatoid arthritis via TGFbeta. J Exp Med 204 (1):33-9.

Nakagiri, T., M. Inoue, E. Morii, M. Minami, N. Sawabata, T. Utsumi, Y. Kadota, K. Ideguchi, T. Tokunaga, and M. Okumura. 2010. Local IL-17 production and a decrease in peripheral blood regulatory $\mathrm{T}$ cells in an animal model of bronchiolitis obliterans. Transplantation 89 (11):1312-9.

Nurieva, R. I., Y. Chung, D. Hwang, X. O. Yang, H. S. Kang, L. Ma, Y. H. Wang, S. S. Watowich, A. M. Jetten, Q. Tian, and C. Dong. 2008. Generation of T follicular helper cells is mediated by interleukin-21 but independent of T helper 1, 2, or 17 cell lineages. Immunity 29 (1):138-49.

O'Shea, J. J., and W. E. Paul. 2010. Mechanisms underlying lineage commitment and plasticity of helper CD4+ T cells. Science 327 (5969):1098-102.

Ouyang, W., J. K. Kolls, and Y. Zheng. 2008. The biological functions of T helper 17 cell effector cytokines in inflammation. Immunity 28 (4):454-67.

Park, H., Z. Li, X. O. Yang, S. H. Chang, R. Nurieva, Y. H. Wang, Y. Wang, L. Hood, Z. Zhu, Q. Tian, and C. Dong. 2005. A distinct lineage of CD4 T cells regulates tissue inflammation by producing interleukin 17. Nat Immunol 6 (11):1133-41. 
Pene, J., S. Chevalier, L. Preisser, E. Venereau, M. H. Guilleux, S. Ghannam, J. P. Moles, Y. Danger, E. Ravon, S. Lesaux, H. Yssel, and H. Gascan. 2008. Chronically inflamed human tissues are infiltrated by highly differentiated Th17 lymphocytes. J Immunol 180 (11):7423-30.

Piccotti, J. R., S. Y. Chan, A. M. VanBuskirk, E. J. Eichwald, and D. K. Bishop. 1997. Are Th2 helper T lymphocytes beneficial, deleterious, or irrelevant in promoting allograft survival? Transplantation 63 (5):619-24.

Prause, O., S. Bozinovski, G. P. Anderson, and A. Linden. 2004. Increased matrix metalloproteinase-9 concentration and activity after stimulation with interleukin-17 in mouse airways. Thorax 59 (4):313-7.

Rahman, M. S., J. Yang, L. Y. Shan, H. Unruh, X. Yang, A. J. Halayko, and A. S. Gounni. 2005. IL-17R activation of human airway smooth muscle cells induces CXCL-8 production via a transcriptional-dependent mechanism. Clin Immunol 115 (3):26876.

Rao, D. A., K. J. Tracey, and J. S. Pober. 2007. IL-1alpha and IL-1beta are endogenous mediators linking cell injury to the adaptive alloimmune response. J Immunol 179 (10):6536-46.

Romani, L., F. Fallarino, A. De Luca, C. Montagnoli, C. D'Angelo, T. Zelante, C. Vacca, F. Bistoni, M. C. Fioretti, U. Grohmann, B. H. Segal, and P. Puccetti. 2008. Defective tryptophan catabolism underlies inflammation in mouse chronic granulomatous disease. Nature 451 (7175):211-5.

Rosen, Y. 2007. Pathology of sarcoidosis. Semin Respir Crit Care Med 28 (1):36-52.

Rouvier, E., M. F. Luciani, M. G. Mattei, F. Denizot, and P. Golstein. 1993. CTLA-8, cloned from an activated T cell, bearing AU-rich messenger RNA instability sequences, and homologous to a herpesvirus saimiri gene. J Immunol 150 (12):5445-56.

Rudner, X. L., K. I. Happel, E. A. Young, and J. E. Shellito. 2007. Interleukin-23 (IL-23)-IL-17 cytokine axis in murine Pneumocystis carinii infection. Infect Immun 75 (6):3055-61.

Sallusto, F., C. R. Mackay, and A. Lanzavecchia. 2000. The role of chemokine receptors in primary, effector, and memory immune responses. Annu Rev Immunol 18:593-620.

Santarlasci, V., L. Maggi, M. Capone, F. Frosali, V. Querci, R. De Palma, F. Liotta, L. Cosmi, E. Maggi, S. Romagnani, and F. Annunziato. 2009. TGF-beta indirectly favors the development of human Th17 cells by inhibiting Th1 cells. Eur J Immunol 39 (1):20715.

Schnyder-Candrian, S., D. Togbe, I. Couillin, I. Mercier, F. Brombacher, V. Quesniaux, F. Fossiez, B. Ryffel, and B. Schnyder. 2006. Interleukin-17 is a negative regulator of established allergic asthma. J Exp Med 203 (12):2715-25.

Schwarzenberger, P., V. La Russa, A. Miller, P. Ye, W. Huang, A. Zieske, S. Nelson, G. J. Bagby, D. Stoltz, R. L. Mynatt, M. Spriggs, and J. K. Kolls. 1998. IL-17 stimulates granulopoiesis in mice: use of an alternate, novel gene therapy-derived method for in vivo evaluation of cytokines. J Immunol 161 (11):6383-9.

Seemungal, T. A., T. M. Wilkinson, J. R. Hurst, W. R. Perera, R. J. Sapsford, and J. A. Wedzicha. 2008. Long-term erythromycin therapy is associated with decreased chronic obstructive pulmonary disease exacerbations. Am J Respir Crit Care Med 178 (11):1139-47.

Shilling, R. A., and D. S. Wilkes. 2011. Role of Th17 cells and IL-17 in lung transplant rejection. Semin Immunopathol. 
Simonian, P. L., C. L. Roark, F. Wehrmann, A. K. Lanham, F. Diaz del Valle, W. K. Born, R. L. O'Brien, and A. P. Fontenot. 2009. Th17-polarized immune response in a murine model of hypersensitivity pneumonitis and lung fibrosis. J Immunol 182 (1):657-65.

Snell, G. I., B. J. Levvey, L. Zheng, M. Bailey, B. Orsida, T. J. Williams, and T. C. Kotsimbos. 2007. Interleukin-17 and airway inflammation: a longitudinal airway biopsy study after lung transplantation. J Heart Lung Transplant 26 (7):669-74.

Song, C., L. Luo, Z. Lei, B. Li, Z. Liang, G. Liu, D. Li, G. Zhang, B. Huang, and Z. H. Feng. 2008. IL-17-producing alveolar macrophages mediate allergic lung inflammation related to asthma. J Immunol 181 (9):6117-24.

Spits, H., and J. P. Di Santo. 2011. The expanding family of innate lymphoid cells: regulators and effectors of immunity and tissue remodeling. Nat Immunol 12 (1):21-7.

Sullivan, A. K., P. L. Simonian, M. T. Falta, J. D. Mitchell, G. P. Cosgrove, K. K. Brown, B. L. Kotzin, N. F. Voelkel, and A. P. Fontenot. 2005. Oligoclonal CD4+ T cells in the lungs of patients with severe emphysema. Am J Respir Crit Care Med 172 (5):590-6.

Sutton, C. E., S. J. Lalor, C. M. Sweeney, C. F. Brereton, E. C. Lavelle, and K. H. Mills. 2009. Interleukin-1 and IL-23 induce innate IL-17 production from gammadelta T cells, amplifying Th17 responses and autoimmunity. Immunity 31 (2):331-41.

Szabo, S. J., S. T. Kim, G. L. Costa, X. Zhang, C. G. Fathman, and L. H. Glimcher. 2000. A novel transcription factor, T-bet, directs Th1 lineage commitment. Cell 100 (6):65569.

Tan, H. L., N. Regamey, S. Brown, A. Bush, C. M. Lloyd, and J. C. Davies. 2011. The th17 pathway in cystic fibrosis lung disease. Am J Respir Crit Care Med 184 (2):252-8.

ten Berge, B., M.S. Paats, I. Bergen, B. van den Blink, H. C. Hoogsteden, B. N. Lambrecht, R. W. Hendriks, and A. KleinJan. 2011. Increased IL-17A expression in granulomas and in circulating memory $\mathrm{T}$ cells in sarcoidosis. Rheumatology in press.

Tesmer, L. A., S. K. Lundy, S. Sarkar, and D. A. Fox. 2008. Th17 cells in human disease. Immunol Rev 223:87-113.

Trifari, S., C. D. Kaplan, E. H. Tran, N. K. Crellin, and H. Spits. 2009. Identification of a human helper $\mathrm{T}$ cell population that has abundant production of interleukin 22 and is distinct from $\mathrm{T}(\mathrm{H})-17, \mathrm{~T}(\mathrm{H}) 1$ and $\mathrm{T}(\mathrm{H}) 2$ cells. Nat Immunol 10 (8):864-71.

Turato, G., R. Zuin, M. Miniati, S. Baraldo, F. Rea, B. Beghe, S. Monti, B. Formichi, P. Boschetto, S. Harari, A. Papi, P. Maestrelli, L. M. Fabbri, and M. Saetta. 2002. Airway inflammation in severe chronic obstructive pulmonary disease: relationship with lung function and radiologic emphysema. Am J Respir Crit Care Med 166 (1):105-10.

Vaknin-Dembinsky, A., K. Balashov, and H. L. Weiner. 2006. IL-23 is increased in dendritic cells in multiple sclerosis and down-regulation of IL-23 by antisense oligos increases dendritic cell IL-10 production. J Immunol 176 (12):7768-74.

Valentine, V. G., M. R. Gupta, J. E. Walker, Jr., L. Seoane, R. W. Bonvillain, G. A. Lombard, D. Weill, and G. S. Dhillon. 2009. Effect of etiology and timing of respiratory tract infections on development of bronchiolitis obliterans syndrome. J Heart Lung Transplant 28 (2):163-9.

Van Kooten, C., J. G. Boonstra, M. E. Paape, F. Fossiez, J. Banchereau, S. Lebecque, J. A. Bruijn, J. W. De Fijter, L. A. Van Es, and M. R. Daha. 1998. Interleukin-17 activates human renal epithelial cells in vitro and is expressed during renal allograft rejection. J Am Soc Nephrol 9 (8):1526-34. 
Vanaudenaerde, B. M., S. I. De Vleeschauwer, R. Vos, I. Meyts, D. M. Bullens, V. Reynders, W. A. Wuyts, D. E. Van Raemdonck, L. J. Dupont, and G. M. Verleden. 2008. The role of the IL23/IL17 axis in bronchiolitis obliterans syndrome after lung transplantation. Am J Transplant 8 (9):1911-20.

Vanaudenaerde, B. M., L. J. Dupont, W. A. Wuyts, E. K. Verbeken, I. Meyts, D. M. Bullens, E. Dilissen, L. Luyts, D. E. Van Raemdonck, and G. M. Verleden. 2006. The role of interleukin-17 during acute rejection after lung transplantation. Eur Respir J 27 (4):779-87.

Vanaudenaerde, B. M., S. E. Verleden, R. Vos, S. I. Vleeschauwer, A. Willems-Widyastuti, R. Geenens, D. E. Raemdonck, L. J. Dupont, E. K. Verbeken, and I. Meyts. 2011. Innate and Adaptive Interleukin-17-producing Lymphocytes in Chronic Inflammatory Lung Disorders. Am J Respir Crit Care Med 183 (8):977-86.

Vanaudenaerde, B. M., W. A. Wuyts, N. Geudens, T. S. Nawrot, R. Vos, L. J. Dupont, D. E. Van Raemdonck, and G. M. Verleden. 2008. Broncho-alveolar lavage fluid recovery correlates with airway neutrophilia in lung transplant patients. Respir Med 102 (3):339-47.

Veldhoen, M., R. J. Hocking, C. J. Atkins, R. M. Locksley, and B. Stockinger. 2006. TGFbeta in the context of an inflammatory cytokine milieu supports de novo differentiation of IL-17-producing T cells. Immunity 24 (2):179-89.

Vogelzang, A., H. M. McGuire, D. Yu, J. Sprent, C. R. Mackay, and C. King. 2008. A fundamental role for interleukin-21 in the generation of $\mathrm{T}$ follicular helper cells. Immunity 29 (1):127-37.

Volpe, E., N. Servant, R. Zollinger, S. I. Bogiatzi, P. Hupe, E. Barillot, and V. Soumelis. 2008. A critical function for transforming growth factor-beta, interleukin 23 and proinflammatory cytokines in driving and modulating human $\mathrm{T}(\mathrm{H})-17$ responses. Nat Immunol 9 (6):650-7.

Wang, Y. H., K. S. Voo, B. Liu, C. Y. Chen, B. Uygungil, W. Spoede, J. A. Bernstein, D. P. Huston, and Y. J. Liu. 2010. A novel subset of CD4(+) T(H)2 memory/effector cells that produce inflammatory IL-17 cytokine and promote the exacerbation of chronic allergic asthma. J Exp Med 207 (11):2479-91.

Weaver, C. T., and R. D. Hatton. 2009. Interplay between the TH17 and TReg cell lineages: a (co-)evolutionary perspective. Nat Rev Immunol 9 (12):883-9.

Weaver, C. T., R. D. Hatton, P. R. Mangan, and L. E. Harrington. 2007. IL-17 family cytokines and the expanding diversity of effector T cell lineages. Annu Rev Immunol 25:821-52.

Wiehler, S., and D. Proud. 2007. Interleukin-17A modulates human airway epithelial responses to human rhinovirus infection. Am J Physiol Lung Cell Mol Physiol 293 (2):L505-15.

Wills-Karp, M., J. Luyimbazi, X. Xu, B. Schofield, T. Y. Neben, C. L. Karp, and D. D. Donaldson. 1998. Interleukin-13: central mediator of allergic asthma. Science 282 (5397):2258-61.

Wilson, M. S., S. K. Madala, T. R. Ramalingam, B. R. Gochuico, I. O. Rosas, A. W. Cheever, and T. A. Wynn. 2010. Bleomycin and IL-1beta-mediated pulmonary fibrosis is IL17A dependent. J Exp Med 207 (3):535-52.

Wilson, N. J., K. Boniface, J. R. Chan, B. S. McKenzie, W. M. Blumenschein, J. D. Mattson, B. Basham, K. Smith, T. Chen, F. Morel, J. C. Lecron, R. A. Kastelein, D. J. Cua, T. K. 
McClanahan, E. P. Bowman, and R. de Waal Malefyt. 2007. Development, cytokine profile and function of human interleukin 17-producing helper T cells. Nat Immunol 8 (9):950-7.

Wolff, A. J., and A. E. O'Donnell. 2003. HIV-related pulmonary infections: a review of the recent literature. Curr Opin Pulm Med 9 (3):210-4.

Wu, Q., R. J. Martin, J. G. Rino, R. Breed, R. M. Torres, and H. W. Chu. 2007. IL-23dependent IL-17 production is essential in neutrophil recruitment and activity in mouse lung defense against respiratory Mycoplasma pneumoniae infection. Microbes Infect 9 (1):78-86.

Yang, L., D. E. Anderson, C. Baecher-Allan, W. D. Hastings, E. Bettelli, M. Oukka, V. K. Kuchroo, and D. A. Hafler. 2008. IL-21 and TGF-beta are required for differentiation of human T(H)17 cells. Nature 454 (7202):350-2.

Yang, X. O., S. H. Chang, H. Park, R. Nurieva, B. Shah, L. Acero, Y. H. Wang, K. S. Schluns, R. R. Broaddus, Z. Zhu, and C. Dong. 2008. Regulation of inflammatory responses by IL-17F. J Exp Med 205 (5):1063-75.

Yao, C., D. Sakata, Y. Esaki, Y. Li, T. Matsuoka, K. Kuroiwa, Y. Sugimoto, and S. Narumiya. 2009. Prostaglandin E2-EP4 signaling promotes immune inflammation through Th1 cell differentiation and Th17 cell expansion. Nat Med 15 (6):633-40.

Yao, Z., W. C. Fanslow, M. F. Seldin, A. M. Rousseau, S. L. Painter, M. R. Comeau, J. I. Cohen, and M. K. Spriggs. 1995. Herpesvirus Saimiri encodes a new cytokine, IL17, which binds to a novel cytokine receptor. Immunity 3 (6):811-21.

Ye, P., F. H. Rodriguez, S. Kanaly, K. L. Stocking, J. Schurr, P. Schwarzenberger, P. Oliver, W. Huang, P. Zhang, J. Zhang, J. E. Shellito, G. J. Bagby, S. Nelson, K. Charrier, J. J. Peschon, and J. K. Kolls. 2001. Requirement of interleukin 17 receptor signaling for lung CXC chemokine and granulocyte colony-stimulating factor expression, neutrophil recruitment, and host defense. J Exp Med 194 (4):519-27.

Yokota, S., T. Miyamae, T. Imagawa, N. Iwata, S. Katakura, M. Mori, P. Woo, N. Nishimoto, K. Yoshizaki, and T. Kishimoto. 2005. Therapeutic efficacy of humanized recombinant anti-interleukin-6 receptor antibody in children with systemic-onset juvenile idiopathic arthritis. Arthritis Rheum 52 (3):818-25.

Yoshida, S., A. Haque, T. Mizobuchi, T. Iwata, M. Chiyo, T. J. Webb, L. A. Baldridge, K. M. Heidler, O. W. Cummings, T. Fujisawa, J. S. Blum, D. D. Brand, and D. S. Wilkes. 2006. Anti-type V collagen lymphocytes that express IL-17 and IL-23 induce rejection pathology in fresh and well-healed lung transplants. Am J Transplant 6 (4):724-35.

Young, D. A., M. Hegen, H. L. Ma, M. J. Whitters, L. M. Albert, L. Lowe, M. Senices, P. W. Wu, B. Sibley, Y. Leathurby, T. P. Brown, C. Nickerson-Nutter, J. C. Keith, Jr., and M. Collins. 2007. Blockade of the interleukin-21/interleukin-21 receptor pathway ameliorates disease in animal models of rheumatoid arthritis. Arthritis Rheum 56 (4):1152-63.

Yusuf, I., R. Kageyama, L. Monticelli, R. J. Johnston, D. Ditoro, K. Hansen, B. Barnett, and S. Crotty. 2010. Germinal center T follicular helper cell IL-4 production is dependent on signaling lymphocytic activation molecule receptor (CD150). J Immunol 185 (1):190-202.

Zaba, L. C., G. P. Smith, M. Sanchez, and S. D. Prystowsky. 2010. Dendritic cells in the pathogenesis of sarcoidosis. Am J Respir Cell Mol Biol 42 (1):32-9. 
Zheng, W., and R. A. Flavell. 1997. The transcription factor GATA-3 is necessary and sufficient for Th2 cytokine gene expression in CD4 T cells. Cell 89 (4):587-96.

Zheng, Y., P. A. Valdez, D. M. Danilenko, Y. Hu, S. M. Sa, Q. Gong, A. R. Abbas, Z. Modrusan, N. Ghilardi, F. J. de Sauvage, and W. Ouyang. 2008. Interleukin-22 mediates early host defense against attaching and effacing bacterial pathogens. Nat Med 14 (3):282-9. 


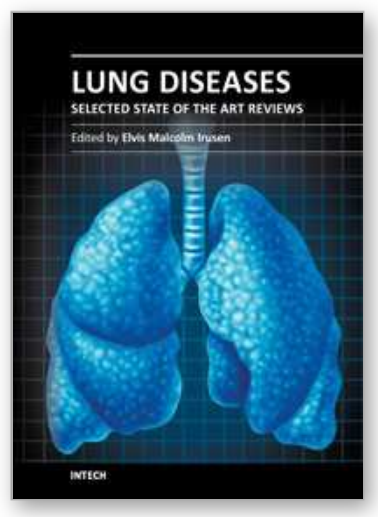

\section{Lung Diseases - Selected State of the Art Reviews}

Edited by Dr. Elvisegran Malcolm Irusen

ISBN 978-953-51-0180-2

Hard cover, 690 pages

Publisher InTech

Published online 02, March, 2012

Published in print edition March, 2012

The developments in molecular medicine are transforming respiratory medicine. Leading clinicians and scientists in the world have brought their knowledge and experience in their contributions to this book. Clinicians and researchers will learn about the most recent advances in a variety of lung diseases that will better enable them to understand respiratory disorders. This treatise presents state of the art essays on airways disease, neoplastic diseases, and pediatric respiratory conditions. Additionally, aspects of immune regulation, respiratory infections, acute lung injury/ARDS, pulmonary edema, functional evaluation in respiratory disorders, and a variety of other conditions are also discussed. The book will be invaluable to clinicians who keep up with the current concepts, improve their diagnostic skills, and understand potential new therapeutic applications in lung diseases, while scientists can contemplate a plethora of new research avenues for exploration.

\section{How to reference}

In order to correctly reference this scholarly work, feel free to copy and paste the following:

M.S. Paats, P.Th.W. van Hal, C.C. Baan, H.C. Hoogsteden, M.M. van der Eerden and R.W. Hendriks (2012). Interleukin-17 and T Helper 17 Cells in Mucosal Immunity of the Lung, Lung Diseases - Selected State of the Art Reviews, Dr. Elvisegran Malcolm Irusen (Ed.), ISBN: 978-953-51-0180-2, InTech, Available from: http://www.intechopen.com/books/lung-diseases-selected-state-of-the-art-reviews/interleukin-17-and-t-helper17-cells-in-mucosal-immunity-of-the-lung

\section{INTECH}

open science | open minds

\section{InTech Europe}

University Campus STeP Ri

Slavka Krautzeka 83/A

51000 Rijeka, Croatia

Phone: +385 (51) 770447

Fax: +385 (51) 686166

www.intechopen.com

\section{InTech China}

Unit 405, Office Block, Hotel Equatorial Shanghai

No.65, Yan An Road (West), Shanghai, 200040, China

中国上海市延安西路65号上海国际贵都大饭店办公楼405单元

Phone: +86-21-62489820

Fax: $+86-21-62489821$ 
(C) 2012 The Author(s). Licensee IntechOpen. This is an open access article distributed under the terms of the Creative Commons Attribution 3.0 License, which permits unrestricted use, distribution, and reproduction in any medium, provided the original work is properly cited. 